\title{
«Dos polos tiene la tierra, / universal movimiento»: Dineros, musas y porfías en la ultima bibliografía lopesca
}

\author{
Miguel García-Bermejo Giner \\ Universidad de Salamanca \\ mencu@usal.es
}

Carmen Sanz Ayán

Hacer escena: capitulos de historia de la empresa teatral en el Siglo de Oro

Madrid, Real Academia de la Historia, 2013, 371 p.

ISBN 978-84-15069-55-3

\section{Alejandro García Reidy}

Las musas rameras. Oficio dramático y conciencia profesional en Lope de Vega

Madrid-Frankfurt, Iberoamericana-Vervuert, 2013, 440 p. ISBN 978-84-84897-43-9

Antonio Cortijo Ocaña

La porfía: identidad personal y nacional en Lope de Vega

Barcelona, Anthropos, 2013, 253 p.

ISBN 978-84-15260-59-2

Los estudios sobre el teatro del Siglo de Oro proliferan en este siglo y abordan minuciosamente asuntos y problemas que hasta ahora se estudiaban con brevedad o se relegaban a una nota al pie. Además, los especialistas del teatro áureo han adoptado la hermenéutica interdisciplinar que Sirera recomendaba perspicazmente, a fines del siglo pasado, para los estudios dramáticos: el empleo de la Historia, gracias al cual podemos «entender no sólo numerosas obras, sino también episodios esenciales de la historia del teatro", y la adopción de «los sistemas de investigación de la historia (y de otras disciplinas 
como la sociología o la antropología» (2007: 16). No obstante, como recuerda con Mainer (2000: 96) Gómez Gómez (2013: 27), mientras que los estudios de historia literaria se han visto sometidos a revisión por los partidarios de la teoría literaria y la interdisciplinariedad, se ha dejado un tanto de lado una perspectiva diacrónica para los fenómenos estudiados, de modo que se prescinde de informaciones históricas y de costumbres dramáticas del siglo XVI que se deben integrar en la explicación del teatro de la primera mitad del siglo XVII.

De ahí que no sea simple azar el que esta reseña recoja tres monografías de temática y metodología distintas. Todas ellas son complementarias y permiten acceder a un panorama en el que se comprenden las decisiones tomadas por Lope de Vega a lo largo de su vida creativa en el mundo del teatro. No se puede estudiar al genial autor sin tener en cuenta el contexto en el que habitó, vivieron sus espectadores, sus protectores, sus mecenas, y, por supuesto, sus detractores. La grandeza de Lope no disminuye un ápice por verlo sujeto a sus deseos o por sus anhelos de reconocimiento social y literario. Si acaso, se aprecia aún más la inteligencia de cómo combina estrategias para obtener sus objetivos sin renunciar a perseguir la excelencia literaria y a probar las corrientes literarias coetáneas, para alcanzar el reconocimiento, relacionado con los procesos de autocanonización literaria contemporáneos, al que siempre aspiró, sin dejar su estilo personal.

Por eso iré de la monografía más general a la más especializada, desde Sanz Ayán, Hacer escena: capitulos de historia de la empresa teatral en el Siglo de Oro (2013) y su análisis de la aparición y desarrollo de la empresa teatral a Las musas rameras. Oficio dramático y conciencia profesional en Lope de Vega, de García Reidy (2013) y su estudio de Lope desde la perspectiva de la figura del autor. Concluiré en fin con el abordaje de la producción dramática de un subtipo de comedias de asunto militar, de las que se ocupa monográficamente Cortijo Ocaña (La porfía: identidad personal y nacional en Lope de Vega, 2013) en su análisis de la función política de algunas comedias de Lope, de tema militar, ambientadas en el conflicto de Flandes.

Mi sistema de trabajo intenta combinar el dar cuenta extensa de los hallazgos principales de los autores y, para utilidad de los lectores de este artículo de revisión, sugerir en ocasiones líneas complementarias de lectura, que en modo alguno suponen una crítica a los contenidos de los textos analizados.

\section{Hacer escena}

Carmen Sanz Ayán

Hacer escena: capitulos de historia de la empresa teatral en el Siglo de Oro

Madrid, Real Academia de la Historia, 2013, 371 p. ISBN 978-84-15069-55-3 
Como sabe quien se dedique a los estudios del teatro áureo, desde las dos últimas décadas del siglo pasado se ha multiplicado la publicación de estudios sobre autores y obras dramáticos, por lo que comienzan ya a aparecer monografías que reúnen diversos artículos de un mismo investigador, publicados o inéditos, sobre un determinado campo de trabajo. Este es el caso del libro de Sanz Ayán (2013), que recopila ocho contribuciones previamente presentadas en congresos y/o publicadas; en ellas analiza tres parcelas del fenómeno dramático del Siglo de Oro en los dos extremos de su arco temporal. Comienza por la influencia que tuvo en el desarrollo y configuración socioeconómica del primer teatro áureo Felipe II y la familia real, estudio que complementa el siguiente capítulo dedicado a la análoga función desempeñada por la Commedia dell'arte en el establecimiento de distintos aspectos de la representación (actores, frecuencias y aspectos económicos). En la sección siguiente aborda la presencia en los textos de aspectos de la crisis fiscal que afectó a los reinados de los dos últimos Austrias menores, así como sus consecuencias para el mundo del espectáculo teatral, que cobra de nuevo protagonismo en la tercera sección, centrada en los actores y autores de comedias, las dificultades que encontraban en su actividad y los recursos de los que disponían, amén de en la cuestión de la incorporación femenina a la dirección de compañías de comedias.

En el primer capítulo — «Felipe II y los orígenes del teatro barroco» (1999) — defiende que la actitud de los Austrias mayores hacia el teatro no fue tan negativa como generalmente se afirma; reúne noticias de cómo Carlos V utilizaba representaciones cortesanas para celebrar acontecimientos señalados de la monarquía y recuerda que Felipe II continuó por esa senda; a pesar de la tradicional aversión hacia el teatro que se le ha supuesto al rey prudente, Sanz Ayán (2013: 21) recuerda cómo, ya cercano a su fallecimiento, ordena que se le traslade en un sillón a una de las galerías de palacio para poder disfrutar desde allí de la máscara con la que ordenó celebrar las bodas del duque de Alcalá, porque al rey le gustaba celebrar con representaciones no sólo las festividades religiosas sino también, por ejemplo, el carnaval o la epifanía.

Los actores de aquellas representaciones tan tempranas no son aún profesionales, sino que proceden de los gremios de oficios mecánicos, como sucede en Francia; posiblemente fueron aficionados que pusieron tanto empeño en la representación que acabaron por convertirse en semiprofesionales de la representación. La Casa Real impulsó el desarrollo de estas agrupaciones cuando comenzó a contratar a estas compañías en agraz en la década de los 60 para representaciones en palacio, para solaz de toda la familia real, incluido un Felipe II que no podía contener la risa ante un calculadamente rústico Alonso de Cisneros. La familia real disfrutaba de representaciones particulares de varios temas, del teatro de colegio a la commedia dell'arte pasando por danzas que parecen antecedentes de la mojiganga (2013: 34-41).

El teatro está asentado en la sociedad española del xvi como medio de celebración y fuente de diversión; se encontraba profundamente arraigado en la 
cultura urbana y, como sucedía en el resto de Europa, se había transformado en una actividad que producía beneficios monetarios merced a la instauración de la representación en recintos cerrados en los que se puede contemplar un espectáculo a cambio de una entrada. La diferencia frente a otras urbes es que en Madrid el establecimiento de la Corte aceleró el proceso migratorio iniciado con anterioridad y que desembocó en una explosión demográfica a partir de 1561, para pasar de 9000 a 83000 habitantes a finales de siglo. A los privilegiados que se reúnen en torno a los reyes se les une una legión de desarraigados en busca de dudosas oportunidades que engrosan los márgenes de la sociedad y que tenían como única opción acudir a los centros de caridad, que pronto se revelaron incapaces de atender el crecimiento exponencial de población. Esas necesidades hicieron proliferar las conocidas cofradias de socorro, cuyos medios consuetudinarios pronto se revelaron insuficientes y terminaron por obtener la concesión del monopolio de la gestión comercial del teatro público. Curiosamente, como señala la autora, el fenómeno se produjo durante los años en que la consorte del monarca español es Isabel de Valois, una francesa que había conocido cómo en París desde 1402 una cofradía del mismo nombre que la española había recibido un similar privilegio con idénticos fines asistenciales. A pesar de las diferencias que la propia autora señala, también recuerda cómo el autor de comedias de más éxito del momento, Jerónimo Velázquez, era cofrade de las asociaciones conocidas que se encuentran tras la explotación de los primeros corrales.

El sistema prendió en los territorios europeos administrados por la corona española, de Lisboa a Nápoles, pasando por diversas fundaciones en la península, aunque en Sevilla la iniciativa privada respaldara la apertura de un número importante de corrales. La vinculación del teatro con la actividad asistencial pudo ser también un intento de contrarrestar la imagen negativa que predicadores, eclesiásticos e incluso algunos pensadores contemporáneos tenían del teatro. La actitud de Felipe II, en cuanto gobernante, ante esta explosión de actividades teatrales fue la de no entorpecerlas e incluso propiciarlas. A rey le fascinaron Ganassa y otros comediantes italianos - como sabemos por la información magnífica reunida por Ferrer Valls (2013) - por lo que concedió un permiso especial al primero para representar en corrales que funcionaban los días laborables además de domingos y festivos, lo cual suponía una notable cantidad de ingresos. Esto llevó a los autores de comedias españoles a solicitar el mismo privilegio; la aceptación de las autoridades de Madrid, temerosas de que las compañías no acudiesen a la capital en Corpus, atraídas por los beneficios de los espectáculos consolidados de otras ciudades como Sevilla o Toledo, produjo que acabasen por aceptar tal petición. Pero con ello se alzaron las voces de quienes se preocupaban por el efecto que esa tentadora oferta de ocio diaria produjera, máxime cuando además había actrices sobre el tablado. Aborda por ello la autora la cuestión de la presencia de mujeres en escena, atestiguada tempranamente, con condición de actividad profesional desde mediados del siglo hasta la prohibición de 1586, contestada por las propias actrices al año siguiente con el poderoso argumento de que la moralidad se vería 
más afectada por unas mujeres sin recursos por su salida de la escena que por su presencia sobre las tablas. El Procurador General de la Villa de Madrid, en nombre de las cofradías de la Pasión y de la Soledad y de los representantes del Hospital General, se adhirió, ante el descenso de ingresos. Ante todo ello, Felipe II con una respuesta en la que añade personalmente argumentos, no sin oposición de algún moralista, termina levantando la prohibición y aceptando, con las condiciones conocidas, que las mujeres representasen en los escenarios españoles.

Al final de su reinado el monarca volvió, por influjo de sus consejeros religiosos, a endurecer la legislación, aunque fue el fallecimiento de diversos miembros de la familia Real lo que produjo el cierre de los teatros madrileños en señal de duelo, que se prolongó con su fallecimiento en septiembre de 1598. Pero la presión combinada de actores e instituciones produjeron que el 17 de abril de 1599, tras la Cuaresma, coincidiendo con las bodas de Felipe III y Margarita de Austria, se levantase la prohibición.

En el segundo capítulo ("Los cómicos dell'Arte y el desarrollo del "negocio teatral" a fines del siglo XVI»), Sanz Ayán explora la relevancia que tuvo la presencia de compañías italianas, y en especial la de Alberto Naselli, "Ganassa», en el desarrollo comercial del teatro español. Tras una sintética presentación de la muy conocida commedia dell'arte, resume los datos biográficos de Ganassa y sus actividades. Estudia su actividad en Madrid y destaca su iniciativa de invertir parte de sus ganancias en el acondicionamiento del recinto donde representa, el corral de la Pacheca, con el fin de acoger más público y que estuviese más cómodo, reformando el techado e incorporando un toldo que lo protegiese del sol en verano. Más adelante, y cuando ya se había completado casi la construcción del corral del Príncipe, sufragó la apertura de nuevas ventanas y la creación de aposentos. Su ejemplo fue un acicate para el cambio de otros autores de comedias autóctonos, tanto en la cuestión puramente escénica como en la de la gestión económica de los espectáculos, que buscaban mejorar con la reforma de los corrales.

Los cambios que introdujo el italiano también tuvieron que ver con el aumento del número de representaciones semanales. Su obtención de una licencia regia para representar en dos días laborables, como había intentado sin éxito en Francia, levantaron las protestas de las discriminadas compañías locales, que no tenían este privilegio; su decisión de sufragar reformas de los corrales parece que no fue ajena a conseguir las mismas condiciones para sus compañías, que lograron al año siguiente aunque sólo para la Corte.

La compañía de Ganassa, como era normal en la commedia italiana, empleaba actrices, que además eran ingrediente esencial de su éxito, por sus dotes dramáticas y por la atención que concitaban de los espectadores masculinos. La prohibición de subir al escenario actrices, de 1587, no impidió que Silvia Roncalli, «La Franceschina" y sus compañeras actuaran, merced a una licencia real, prerrogativa que otros autores de comedias como Alonso de Cisneros también reclamaron.

A la luz de estos hechos no es de extrañar que sus ganancias fueran más que notables, como se ha podido averiguar gracias al Libro de los asientos del producto 
de comedias de las cofradías de la Pasión y la Soledad, aunque las cantidades reflejan lo que percibían estas entidades de la recaudación generada por Ganassa, y por tanto no son las ganancias totales del italiano. Como es lógico, las ganancias son superiores el primer año a las del resto, dada la novedad. El aparato que anunciaba la entrada de la compañía en la ciudad explicaba la expectación del público; la autora alude al texto de Garzoni (1585: 755), pero no lo reproduce, aunque creo que es de gran interés:

"Come entrano questi dentro a una città, súbito col tamburo a si fa sapere, che i signori Comici tali sono arrivati, andado la Signora vestita da huomo con la spada in mano a fare la rassegna, e s'invita al popolo a una comedia, o tragedia o pastorale in Palazzo o all'Hostaria del Pellegrino, ove la pleble, desiosa di cose nuove e curiosa per sua natura, subito s'affreta a ocupar la stanza e si passa permezzo di gazette dentro alla sala preparata. E qui si trova un palco postizzo, una scena dipinta col carbone senza un giudicio al mondo; s'ode un concertó antecedente d'asini e galarboni, si sente un prologo da ceretano ${ }^{1}$, un tono goffo come quel di fra Stoppino, atti rincrescevoli come il mal'anno, intermedii da mille forche, un Magnifico che non vale un bezzo, un Zani che pare un'occa, un Gratiano che caca le parole, una rufiana insulsa e scioccarella, uno innamorato che stroppia le braccia a tuti quando favella, un Spagnolo che non sa proferir se non: "Mi vida e mi corazon!", un pedante che scarta nelle parole toscane a ogni tratto, un Burattino che non sa far altro gesto che quello del berettino che si mette in capo, una Signora sopra tutto orca nel dire, morta nel favellare, addormentata nel gestire, c'ha perpetua inimicitia con le gratie et tien con la belleza differenza capitale. Si che il popolo tutto parte scandalizato e mal sodisfatto di costoro, portando oltra di cio nella memoria i bruttisimi ragionamenti recitati ne la seguente sera spenderebbe un bagatino per sentir di nuovo cotali sciocchezze già per tutta la terra, con beste d'ognuno divulgate e esparse».

Tras el éxito, en los años siguientes las cantidades se estabilizaron y descendieron, como también lo hizo el número de representaciones realizadas en Madrid. Sus competidores, Jerónimo Velázquez y el célebre Cisneros, adoptaron parte de las innovaciones que proporcionaron éxito al italiano, en especial en lo referente a las fórmulas empresariales. A la larga los autores de comedias españoles acabarían imponiéndose por factores varios relacionados con el público (agotamiento de la novedad, dificultades con el idioma). Si en Europa la fórmula italiana continuó hasta el siglo siguiente o más allá, en el reino de España pronto se produjeron hibridaciones con la tradición dramática autóctona como la de Abagaro Frescobaldi. En esta sección se echa en falta el haber consultado las novedades, abundantes y

1. El propio Garzoni describe la forma de presentarse en escena de este «charlatán»: «Or per non fare un prologo de ceretano - se ben porto la maschera agli occhi da astrolo- m'aacingo or ora a forbire il muso a molti mamalucchi, il quali su le piazze e botteghe raduano il circolo mentre parlano dell'astrolabio, del scioterio, del qadrante, del direttorio, mentre meglio si convien loro un ciffolotto un mano e un capapensiero in bocca, essendo insipidi nel sermone più che un zocco» (1993: 604). 
de calado, que ha reunido el DICAT (2008) de Ferrer Valls. A partir de entonces fueron los autores, actores y compañías españolas las que triunfaron en los escenarios italianos. A esa adopción tuvo que contribuir una comunidad de rasgos compartida con los textos italianos: estar divididos en tres actos, el equilibrio y la doble trama en argumentos en acciones o la acción amorosa con final feliz. También allí se produjeron interesantes fenómenos de mestizaje como en el caso de Beatriz de Guzmán, quien bailaba en los entremeses de Antonio Melo, napolitano de origen luso, famoso por sus representaciones como capitano Flegetonte; al respecto véanse las noticias de D'Antuono (1999: 3-4).

Este último aspecto de la difusión del teatro español por Europa es el tema del tercer capítulo, previamente publicado en versión más extensa (“"Ecos de comedia": influencias del teatro español en el sacro imperio y los Países Bajos en tiempos de los Austrias» 2003). Con documentos manuscritos, pertenecientes a mercaderes centroeuropeos, alguno de origen judeoconverso, y españoles radicados en aquellas tierras, da cuenta Sanz Ayán de la extensión geográfica de los lectores de textos literarios españoles del barroco. Esas noticias las complementa con personajes que aparecen en textos españoles dramáticos adaptados. Son sólo cinco ejemplos, pero muestran el tráfico cultural y literario, sea por medio de impresos, manuscritos o personas, que tuvo lugar en el XVI y XVII en los territorios gobernados por las dos ramas de la dinastía Habsburgo. No hubiera estado de más, para poner en perspectiva el éxito del drama barroco, aludir mínimamente a las traducciones y adaptaciones de textos dramáticos en Italia con Profeti (2009: 371-466), en Francia, con Couderc (2007: 317-344) o los abordajes que recoge el citado Courderc (2012), o Inglaterra, con Paun de García (ed.) (2008).

Antes de abordar la difusión de la comedia espańola, la autora presenta el teatro autóctono de cada uno de los países en que estudia la recepción del teatro áureo. En el caso alemán, pasa revista al teatro jesuítico y sus recursos, difundido a pesar de la dificultad que implicaba el empleo del latín, sin advertir que, como en el mundo universitario del renacimiento, era un instrumento de enseńanza de esa lengua clásica. Este teatro misionero jesuítico se separó, por su efectismo, del drama humanista y del teatro de escuela protestante. En la versión original de su trabajo había incluido una serie de referencias bibliográficas que permitían completar el panorama, que se podría completar ahora con materiales a los que la autora no pudo tener acceso en el momento de la redacción de su estudio, como las monografías de Bloemendal (2008), Norland \& Bloemental (eds.) (2013) y Ford \& Taylor (2013).

Explica a continuación la presencia de obras españolas en los escenarios de los Países Bajos (Ámsterdam, Amberes y Bruselas, especialmente) por varias razones. Encuentra una distribución geográfica de las causas: en las provincias del Sur, la burguesía media y alta recibió una fuerte influencia española por el establecimiento de Isabel Clara Eugenia y el archiduque Alberto de Austria en Bruselas como soberanos entre 1598 y 1621; de hecho, Isabel Clara fue gober- 
nadora hasta 1633. A Bruselas llegaron compañías españolas cuya actividad y periplo están todavía por estudiar, aunque tal vez fuera la población española residente en Bruselas la que explique su presencia y no sólo los impresos que se importan desde España. Además recoge otros autores belgas que escriben en castellano obras que imitan las españolas, que conocían de primera mano por haber residido largas temporadas en España. En las provincias del norte la literatura española es mucho más influyente que otras. A ello contribuyeron grandemente los sefarditas, mayormente conversos españoles que volvieron a su religión cuando se instalaron en Ámsterdam. Aunque se les dispensó un trato cruel, seguían deseosos de mantener el contacto por razones comerciales y financieras, y también por sus gustos literarios, con su añorada Sefarad. Por eso surgen academias literarias en la segunda mitad del XVII que se inspiran más en el modelo español que en el holandés, tanto por el idioma en que desarrollaban sus actividades como también por cierto carácter aristocrático. Las actividades literarias de sus miembros incluían la creación poética, en hebreo, de tipo religioso, pero también de contenido profano, como las comedias que escribe Miguel de Barrios y publica en 1665 junto con otras obras en su compilación Flor de Apolo. Se conocen además noticias de montajes privados de comedias españolas y representaciones en casas particulares de obras de éxito en la España contemporánea para festejar acontecimientos como esponsales privados. Con teatro español se celebraban también algunos enlaces aristocráticos, a pesar de las diferencias políticas existentes entre las provincias del Norte y las del Sur.

El éxito del teatro comercial en las Provincias Unidas, especialmente en Ámsterdam, estuvo estrechamente ligado al desarrollo del teatro comercial, cuya evolución, incluido su empleo para sufragar entidades asistenciales, es muy semejante al español. Desde 1638 se representaron más de 40 comedias españolas en traducción directa, otras 30 a través de una traducción francesa y 40 más de inspiración española aunque sin una fuente segura. El autor más representado fue Lope de Vega, con obras como La fuerza lastimosa, Los locos de Valencia, Si no vieran las mujeres, El castigo sin venganza, El gran Duque de Moscovia y El molino. A fines del XIx se intentó llevar a cabo un catálogo de las obras dramáticas holandesas inspiradas en comedias españolas y se localizaron 70 títulos, casi todas pertenecientes al periodo 1640-1730. Los traductores en muchas ocasiones eran miembros de las compañías profesionales que representaban los textos, y no trabajaron en solitario sino que contaron con la colaboración de sefardíes que les proporcionaban un texto en prosa a partir del cual los holandeses escribían su versión versificada.

En los territorios de habla alemana, en cambio, no había espacios públicos para la representación, que se realizaba en la corte, en las escuelas y, en las grandes y medianas ciudades comerciales, en las ferias. Allí las comedias españolas se representaron en tres núcleos culturales: la corte de Viena, la ópera de Hamburgo y la compañía de teatro ambulante de Johannes Velten (1640-1693). En el barroco alemán hay una cultura cortesana que impulsa un arte escénico muy 
evolucionado que se manifiesta en lo teatral por la mezcla de música y drama, la ópera. En los años centrales del siglo Xviı se produce el desarrollo de esa conjunción en la escuela protestante dramática, en la ópera de Hamburgo, en el drama católico de las órdenes religiosas y en la consolidación de unos actores que crean sus propios textos para la representación de carácter costumbrista. No son compartimentos estancos sino que tienen vínculos unas con otras (106); de hecho los textos de Calderón fueron adoptados por los libretistas de Hamburgo para un público más amplio especialmente a partir del cuarto del siglo XVII.

La aparición de comediantes profesionales extranjeros comenzó en la región meridional del sacro imperio en los años 60 del xvi, primero con compañías italianas, cerradas a otros textos y lenguajes que no fueran los suyos. Fueron los ingleses, sin embargo, quienes impulsaron en el espacio lingüístico alemán el desarrollo de un teatro profesional. Su repertorio era al comienzo de teatro isabelino, pero pronto introdujeron otras de contenido bíblico y de autores alemanes para, a mediados de siglo, ampliar la oferta incluyendo italianas, españolas (Lope y Calderón) y francesas. A ellas se les debe en Alemania el desarrollo de un teatro profesional consolidado y abierto a todo tipo de público, más interesado en la heterogeneidad de los espectadores que en alcanzar grandes metas artísticas. Las otras entidades que impulsan y disfrutan del teatro, la corte, la escuela protestante o la católica, no llegaron a tener una proyección pública tan extensa como estas compañías itinerantes privadas

Tras esta sección, la autora inicia otra (Entornos y contextos), en la que pasa revista a la presencia que tuvo en el teatro áureo la crisis económica, fiscal y monetaria, que se introdujo en la temática de los textos y en sus estructuras. Comienza el capítulo IV («Peor está que estaba: la crisis hacendística, la cuestión del vellón y su reflejo teatral en tiempos de Calderón, 2003) con el recuerdo de cómo el título de la pieza de Calderón (impresa en 1636) fue empleado por los anónimos autores de una sátira política del siglo Xvir para escribir un falso anuncio de comedia en el que se comparan las medidas de la Real Hacienda del momento con recursos escénicos empleados en el teatro para hacer aparecer o desaparecer, como por arte de magia, personajes en escena, comparaciones que se suman a burlas de empleos de lancetas y otros artilugios médicos destinados a provocar hemorragias en los pacientes, tan fácilmente aplicables a la voracidad recaudatoria de la Hacienda de casi todos los tiempos.

En las representaciones barrocas podemos encontrar reflejo de los problemas económicos de su tiempo, lo que matiza la función propagandística que siempre se les asigna, y que sin duda tuvieron en múltiples ocasiones. Claro que no podemos esperar una crítica transparente y razonada, puesto que en el barroco la expresión es, cuando menos, sutil y generalmente obscura. Por eso no es de extrañar que algunas obras reproduzcan la realidad económica contemporánea, con perspectivas que varían desde la simple narración de los acontecimientos al adoctrinamiento más o menos camuflado con la incorporación de ciertas iniciativas impulsadas por el poder, que, en los autos sacramentales son, curiosamen- 
te, sutilmente censuradas por los graciosos. Así por ejemplo, en El gran teatro del mundo, un labrador se queja de los impuestos que se imponían a los no privilegiados, aunque el grueso de la recaudación procedía de las sisas realizada sobre los consumos en la ciudad. Por extrańo que parezca, los autos sacramentales se emplean también para difundir mensajes políticos, reunidos parcialmente en Latorre Ciria \& Serrano Martín (eds.) (2009); no hay más que recordar alguno de los textos del Códice de autos viejos (Farsa sacramental de la moneda, Farsa del sacramento llamada premática del pan) sobre los que ya llamaba la atención Rodríguez Puértolas (1970), sin olvidar la presencia de personajes políticos en estas piezas en Lope, como estudia Izquierdo Domingo (2013).

La presión fiscal, con todo, no conseguía obtener fondos suficientes para el gasto descontrolado del Reino, por lo que se hubo de conseguir ingresos extraordinarios procedentes «de ventas de privilegios, de oficios, de jurisdicción, de baldíos» o incluso a la manipulación de la aleación de la moneda de vellón, procedimientos impulsados (122) por diferentes arbitristas que son blanco de las críticas de obras como El rey don Pedro en Madrid o el Infanzón de Yllescas, donde el propio rey censura acremente estos procedimientos porque: «[...] no hay arbitrio que sea / a favor de los vasallos». No hay que ver en esa presentación del monarca sensible a los problemas de sus súbditos un ejercicio de lagotería; esta época se aceptaba que la censura podía convivir con la alabanza en cuanto que la segunda proporcionaba un modelo de comportamiento para quien la recibía, porque la obra, de autoría discutida, se escribió cuando se dejan sentir los efectos de la devaluación, hacia 1618 , por lo que chocaban frontalmente las palabras del monarca sobre las tablas con la realidad de las acciones de Felipe III. Calderón incluso critica el sistema empleado en la adjudicación de honores, con el consiguiente ascenso social, por motivos fundamentalmente económicos en El alcaide de si mismo; era frecuente que el Monarca recompensase con títulos a hombres de negocios que habían apoyado las paupérrimas arcas del reino con préstamos y asientos.

Pero si había lugar para las críticas, también cabía la propaganda oficial. Aunque la monarquía española disponía de más medios financieros que ninguna otra de sus contemporáneas, hubo de recurrir a incrementar constantemente la presión fiscal, poco efectiva por la coexistencia de diferentes regulaciones que, además, carecían de aplicación universal, geográfica y socialmente hablando. Además, no existía un aparato administrativo capaz de controlar y gestionar la recaudación, por lo que se recurre a particulares, una delegación que tenía altos costes económicos y sociales. Esa dependencia del crédito privado fue constante y se quiso resolverla creando erarios y montes de piedad que recogieran en depósito los ahorros de los particulares, convirtiéndolos en un empréstito a la corona por el que recibirían un interés adecuado; pero también se puso en marcha una «inflación del vellón», arbitrio dictado por Felipe II pero implementado por Felipe III el 18.09.1693. Consistía en aumentar el valor facial y nominal de las distintas monedas de cobre mediante su resello, una marca que se grababa en ellas con la que se doblaba su valor. Si se pudo enjugar el déficit que padecía 
el reino, en cambio se inició el crecimiento desbocado de la inflación, el acaparamiento de la moneda de plata, la disminución de riqueza de los tenedores de depósitos y deuda del reino y el descabalamiento inmediato del comercio interior. Como señala la autora, no menos del $92 \%$ de todas las transacciones de los españoles del xvıı se realizaban con esa moneda. Estos problemas aparecían en un entremés de Calderón, La rabia, donde un escudero se quejaba: «de que nunca escudo traiga» (129). La medida trajo gran polémica incluso antes de su aplicación y fue objeto de numerosas cábalas y medidas en las Cortes castellanas, de carácter tan arbitristas como las disposiciones que pretendían remediar, y que nunca se llevaron a la práctica.

Los debates en las Cortes se prolongaron seis años, en los que se celebraron las festividades del Corpus de 1624 o 1625, en las que se escenificó una pieza de Mira de Amescua (El Monte de Piedad o Auto del erario y Monte de la Piedad) en la que se introdujeron elementos propagandísticos favorables a esta medida; con ello se perseguía que los procuradores aceptasen las medidas económicas mostrando cómo formaban parte de un propósito mayor con el que no cabía disensión. No fue la única pieza escrita con un propósito; a fines de 1660, Felipe IV se aprestaba a acuñar una nueva moneda de vellón con una ley de plata mínima. Para comenzar la substitución de la antigua moneda por la nueva se necesitaba un millón de ducados en plata con los que financiarla, lo que provocó nuevas disensiones manifestadas sin ambages. La Monarquía quiso convencer aquellos detractores de la necesidad de la medida con un auto sacramental, atribuido a Calderón, El Consumo del vellón (1660) y representado en 1661 en Valladolid, pero que se pudo estrenar antes en Madrid. La obra perseguía impulsar la legitimidad de las reformas económicas impulsadas por la Monarquía frente a sus opositores, que se identifican con enemigos exteriores, sobre quienes nadie alberga ninguna duda sobre su maldad y a los que ningún opositor querría unirse.

En el capítulo siguiente pasa revista a cómo repercute la crisis sobre el universo teatral («La crisis económica durante el reinado de Carlos II y su influencia en el mundo del teatro", 1989). Buena parte de los problemas del último rey de la dinastía de los Habsburgo fueron herencia del caos financiero y hacendístico que produjo Felipe IV. Sanz Ayán (2010) enuncia las dificultades económicas, políticas, militares y agrarias que conducen a que el inicio del reinado de Carlos II se produjese el peor momento de la larga crisis del Reino.

El mundo teatral reflejó estos problemas, que se manifiesta en su aspecto económico con la irrupción, ya en los años 50 del xviI, de la figura del arrendador de corrales; sus cometidos incluían desde la contratación de las compañía hasta aportar financiación para todos los gastos. No es que desempeñaran funciones de banquero, es que eran los profesionales equivalentes de su tiempo a los banqueros, que deciden dedicarse a este nuevo negocio. Según la autora, ya habían comenzado antes de mediados de siglo a interesarse en los posibles beneficios del mundo del teatro, porque los funcionarios públicos nombrados para el manejo administrativo del teatro eran en realidad hombres de negocios integrados en la 
maquinaria financiera del reino; sus cargos en la administración eran un medio de reconocimiento de los servicios prestados al reino y, habitualmente, el único medio al alcance de la corona para devolverles sus préstamos e intereses. Como es lógico, fueron incorporando al teatro sus procedimientos y estrategias habituales, de modo que, por ejemplo, se establecía en los contratos que si se suspende la representación teatral el arrendador no tendría que satisfacer los pagos estipulados, una práctica financiera que era común en los arrendamientos.

En la segunda mitad de los años 80 , se produjo una transformación en el perfil del arrendador de corrales que Varey \& Shergold explicaban como producto de la entrada en el negocio de diletantes, pero que Sanz Ayán supone el producto de la retirada masiva de negociantes de todo tipo de actividades financieras en España; habría sido consecuencia del desconcierto que produjo el proceso de resello iniciado en 1680 . Además, puesto que no era la primera vez que se producía, también influyó la progresiva separación de aquellos hombres de negocios de la administración, que se busca "profesionalizar» con personal que hubiese comenzado su carrera desde la base de las instituciones. Además, se abandonó el arrendamiento de la recaudación de impuestos, que pasaron a ser gestionados directamente por la Hacienda Real, toda vez que se redujeron los impuestos indirectos al consumo.

Quienes deciden implicarse en los arrendamientos del teatro tienen dos motivos: la influencia política y económica que proporciona esos cargos a quienes los desempeñan y la obtención de una parcela de poder político, local en el caso de los arrendadores y que suele traducirse en un nombramiento de regidor. Tales objetivos serían apetecibles solamente a figuras secundarias del mundo financiero, a quienes tuvieron que recurrir los profesionales del teatro ante la retirada de los anteriores para poder mantener una actividad que, tal vez, también iniciara su decadencia por esa retirada de los profesionales.

La tercera parte del estudio (Tópicos a debate) se centra en la figura de los actores y autores de las comedias, sus fortunas y adversidades. Comienza con un elenco de problemas ("Miserias de la comedia”. Algunos problemas del oficio de representar el último cuarto del siglo XVI» 1996) que surgen en preparación de la representación. Los autores de comedias arrostraban graves dificultades en lo relativo a la gestión y obtención de recursos financieros con los que realizar su trabajo. Su instrumento notarial más habitual fue la escritura de obligación, una forma de carta de pago a futuro con la que hacer frente a la falta de liquidez. Si la emplearon para contratar actores y transportar la compañía, también fue un recurso para aumentar y enriquecer el hato, cuya importancia no radicaba solamente en ser un aliciente para conseguir la contratación de la compañía, motivo por el cual se renovaba vestuario en torno a las fechas de obtener encargos de representación, sino también por ser aval habitual en estos acuerdos ante notario. Los fiadores solían ser otros autores de comedias o incluso representantes de la propia compañía; en estas transacciones se solía emplear como aval los futuros ingresos de los encargos obtenidos. Dada la movilidad de las compañías y el uso 
habitual de estas obligaciones, era habitual que se firmasen poderes notariales para poder ser representados en casos de conflicto.

Tampoco eran ajenos los autores al mundo del derecho civil por ser objeto de demandas contra el contenido de alguna de sus obras, o por denuncia de otro autor o actor, o de un acreedor que no hubiese recibido el pago acordado de sus deudas; incluso se podía establecer la exclusividad de la representación de una comedia, cuyo incumplimiento acarreaba pena de prisión. Todo ello podía hacer dar con sus huesos en la cárcel al autor de comedia, como de hecho sucedió a menudo, incluso a personajes como Ganasa o Alonso de Cisneros, entre otras razones por el empleo de la pena de prisión como sanción del impago de deudas en las leyes de Castilla, que además era medida cautelar incluso antes de la ejecución de bienes o pago de lo adeudado. Las distintas administraciones que contrataban las compañías dramáticas acudieron en ocasiones en auxilio de los autores de comedias cuando se enfrentaban a estos problemas, aunque no siempre ni del mismo modo.

También los actores podían verse ente rejas, por deudas o, en ocasiones, merced a una cláusula de penalización que introducían en sus contratos los autores de comedias en virtud de la cual, si rompían su contrato para pasarse a otra compañía, debían responder con ciertas cantidades, lo que suponía su arresto casi inmediato. En algunas ocasiones, sin embargo, la negociación o la mediación de terceros solucionaba el problema, como solía suceder en las peleas entre actores. Caso muy distinto a cuando el enfrentamiento se había producido con personas ajenas a aquel mundo; en ese caso los actores y las compañías tenían que hacer frente a las penas e indemnizaciones dictadas por la ley. Si los autores de comedias empleaban los mismos recursos coercitivos que otros hombres de negocios cuando se trataba de cuestiones económicas, adoptaban, en cambio, una posición mucho más comprensiva cuando afectaban a asuntos profesionales, posiblemente por necesidad de defender una actividad aún incipiente pero fructífera que era muy mal vista por la ortodoxia contemporánea.

El séptimo capítulo recoge una versión de un trabajo previo (2009) en el que estudia el inventario de la biblioteca del autor de comedias Tomás de la Fuente, inserto en su testamento. La autora comienza por repasar la formación cultural de los autores de comedias de fines del siglo xvi. Parte, dejando de lado los anteriores a 1560, de los autores de la época de Lope de Rueda, cuya procedencia profesional artesanal parecía apuntar a que se trataba de iletrados, aunque investigaciones posteriores mostraron que la alfabetización de aquellos artesanos era más alta de lo que se suponía. Lope de Rueda, Timoneda, impresor y librero, «el calcetero Alonso de la Vega [...] el ropero Francisco de la Puente, el hilador Pedro de Montiel, el platero Luis de Cerdeña, el dorador Juan de Salazar, el sastre Diego de Barrio, el tejedor Diego de Pineda, el albañil Jerónimo Velázquez o el también calcetero Tomás Gutiérrez» (193-194) son algunos de los autores agavillados por la autora. Su identificación por medio de su profesión, práctica habitual en el Antiguo Régimen, lleva a que firmen con su nombre 
y ocupación documentos legales, sin que esto implique que mantuvieran esa profesión. Sus anteriores ocupaciones explican su participación ya desde la Edad Media en espectáculos de todo tipo, que conllevaban una celebración comunitaria minuciosamente planificada, para la cual era fundamental el concurso de los distintos gremios de artesanos. Tras de su participación había tanto voluntad de hacerse notar en cuanto colectivo en la comunidad como obediencia al mandato del poder constituido que les conminaba a participar en estos eventos. La colaboración esporádica se hizo progresivamente más y más habitual, por el incremento de festejos similares públicos y privados, e incluso se extendió fuera del lugar de residencia del artesano. Como es lógico, las celebraciones precisaban de unos actores que comenzaron siendo ocasionales pero fueron profesionalizándose por la perspectiva de alcanzar un salario mayor que el que recibían por sus trabajos anteriores. El proceso es similar al que tuvo lugar en Alemania y su asociaciones de canto magistral, los Países Bajos y sus cámaras retóricas, Francia y sus puys, o Inglaterra e Italia con sus gremios.

Los primeros autores de comedias españoles parecían carecer de la formación de sus colegas europeos; el principal hecho que sostiene esta perspectiva es la conocida adquisición de textos para sus compañías, elaborados por autores conocidos o anónimos, que en ocasiones se incorporan al grupo de representantes, como recuerda con Cervantes: «así para enmendar y remendar comedias viejas como para hacerlas de nuevo" (Los trabajos de Persiles y Sigismunda. Ed. Juan Bautista Avalle Arce. Madrid: Cátedra, 1969, 284). Pero también se conserva noticia de los arreglos que realizan los propios autores de comedias de los textos dramáticos para adaptarlos a cada ocasión. No se conservan pruebas de que los escasamente formados directores acudieran a terceros para tales arreglos, por lo que cobra especial relevancia, por lo que implica, el hallazgo de los libros que integraban la biblioteca de Tomás de la Fuente en el inventario de bienes realizado tras su fallecimiento. Los aproximadamente 170 libros que poseía en 1594, y que la autora intenta identificar en apéndice, parecen haber formado parte de una biblioteca profesional.

No hemos conservado abundantes noticias de sus trabajos que permitan conocer integralmente su actividad, aunque Sanz Ayán ha podido rastrear en documentos del Archivo Histórico Provincial de Madrid datos preciosos para reconstruirla con cierta seguridad. Su actividad debió iniciarse a fines de los ańos 70 , pues se encuentra en Madrid intentando formar una compañía en septiembre de 1587. Cuando muere en julio de 1594 se hizo pública almoneda de sus bienes, como era lo habitual, para saldar sus deudas. En ella no se recogen manuscritos con el repertorio de la compañía del autor, por lo que tiene que suponer que debía llevar algunos textos de los escritores de éxito de su tiempo, que mostrarían la coexistencia de público de gustos diversos pero, curiosamente, no aparece textos dramáticos, hecho que la autora explica por haber sido vendidos previamente.

Repasa los 167 volúmenes que integraban la biblioteca del autor de comedias Tomás de la Fuente. Compara sus números con otros de bibliotecas 
privadas de Nueva España, pero no emplea los estudios de Díez Borque (2010 y 2012), que recogen inventarios de la Península Ibérica y arrojan datos con los que contextualizarla. Ha identificado los libros por aproximación del momento del inventario a la fecha de impresión, sin tener en cuenta otras posibles ediciones. Habría sido recomendable emplear ediciones puestas al día de las distintas tipobibliografías, como las de Pérez Pastor (1992) para Medina del Campo, la de Gallego Morell (1997) o la Bibliografia aragonesa de Sánchez (1991); en otras ocasiones se echa en falta el empleo de una tipobibliografía más actualizada, como por ejemplo para Madrid la de Clemente Sanromán (1998) en vez de la benemérita de Pérez Pastor (1891); en varias ocasiones le hubiera sido de utilidad la consulta del Diccionario filológico de literatura española dirigido por Jauralde Pou (2007).

Básicamente son libros en romance, sólo uno en latín (Las Maravillas de Roma), aunque hay trece textos clásicos traducidos (Las Décadas de Tito Livio, los Proverbios y Epistolas de Séneca, Las Moralia de Plutarco, la República de Aristóteles, Salustio, Lucano, dos ediciones distintas de las Metamorfosis ovidianas, Fábulas de Esopo, Solino y Virgilio, etc.). Tenía también textos italianos traducidos de Dante, León Hebreo, Cintio, Bandello o Petrarca. No hay demasiados textos teatrales: un par de Celestinas, un ejemplar de la Primera parte del romancero y tragedias de Lobo Lasso (1587) y otro la Primera parte de las comedias y tragedias de Cueva (1588), así como con un ejemplar de la Florinea de Juan Rodríguez Florián (1554).

Numerosos libros de caballerías, 16 nada menos, entre los que se encuentran del Amadís, al Espejo de Caballerías, amén de Don Belianis, Don Olivante de Laura, Don Florisel de Niquea en sus varias partes, el Palmerín de Oliva, Las sergas de Esplandián o El caballero de la Cruz, por no hablar de los que cita Cervantes en su Quijote, así como Don Cristalián de España, El caballero del Phebo, Lisuarte de Grecia, Leandro el Bel, Segunda de la cuarta de don Florisel de Niquea, Celión de Iberia o Amadis de Grecia. De la ficción sentimental Diego de San Pedro es el único representante.

En poesía encontramos Las trescientas de Juan de Mena, Ausias March y El suceso de Roncesvalles, amén de León de España, Lágrimas de Angélica o el Romancero historiado. Además, el autor poseía un importante número de textos morales y religiosos y de contenido histórico — biografías de hombres ilustres, historias generales de España y particulares de algún territorio, historia militar, etc.— que Sanz Ayán supone fuente de comedias de tipo histórico y autos sacramentales. Además, el autor atesoraba compilaciones de refranes y libros de secretos y misceláneas, amén de tratados políticos y administrativos.

El libro finaliza con el octavo capítulo dedicado a las autoras de comedias en el siglo Xvir en tiempos de Calderón («Las autoras de comedias en el siglo XVII: empresarias teatrales en tiempos de Calderón», 2001).

La presencia de las actrices en la historia del teatro del Siglo de Oro se ha relacionado habitualmente con tres motivos: una anécdota jocosa, la censura 
por algún asunto escabroso o la recopilación de datos dispersos eruditos para construir una biografía lineal. Faltaba siempre un abordaje de conjunto que determinase la función, alcance y evolución de las actividades femeninas en el teatro del Siglo de Oro. De ahí que se eche de menos la integración en este artículo de útiles materiales e informaciones posteriores a la fecha de la primera publicación, como los trabajos de Rodríguez Cuadros (1998) y otros que se contienen en ese volumen, o los reunidos por Martínez Berbel \& Castilla Pérez (eds.) (1998) ó García González (2009) y de Ferrer Valls (2002), especialmente su DICAT (2008).

La mujer en el Siglo de Oro, está sometida a una triple constricción que Sanz Ayán define como "disciplina, claustración y silencio», lo que explica que las actrices que trabajaban en el teatro desde mediados del Xvi fueran condenadas ab initio y sin paliativos como disolutas y estuviesen próximas a la marginación. Tal perspectiva ha sido adoptada casi sin revisión por los estudiosos de épocas posteriores, tal vez, como propone Sanz Ayán, porque son escasas las fuentes que aportan noticias de actrices que se aparten de lo frívolo y anecdótico o por la perspectiva cicatera con la que se ha estudiado la documentación conservada. Esa visión contaminó igualmente los estudios de las otras funciones desempeñadas por mujeres en el teatro del Siglo de Oro en parcelas de gestión y dirección; los estudios realizados hasta ahora se limitaban a tildarlas de profundamente ineficaces en estas tareas, a partir de tomar en consideración sólo los casos desastrados de María de Heredia (1640) y Bárbara Coronel (1676). Por lo general, si el tenor de los juicios sobre la labor femenina al frente de un teatro no iba por esos derroteros, los estudiosos se limitaban a señalar que se trataba de una ocupación desempeñada brevemente por el fallecimiento del marido o porque el paso de los años las había obligado a retirarse de los escenarios. No deja de ser cierto que la temporalidad fue característica de la actividad de las autoras de comedias, pero eso no implica que la calidad de su trabajo se resintiese por ello; tampoco el otoño de la hermosura fue la única causa posible de que se decidiesen a asumir tareas de dirección, puesto que bien pudiera haber sido una consecuencia lógica de la madurez alcanzada con el paso de los ańos.

Desde la consulta directa de materiales diversos la autora propone la existencia de tres fases en el proceso de incorporación femenina a la dirección de compañías dramáticas en el Siglo de Oro. La primera se inicia en los años 40, e incluso en los 30 (2013: 258) del xvi, un momento en el que la falta de reglamentación permitía tanto contratar a solteras para ser actrices como que las esposas de los autores de comedias pudieran desempeñar funciones de representación o dirección en las compañías. La segunda fase se extendería entre la prohibición de 1586 y 1670, fecha en la que se determina que las actrices deben estar subordinadas a su marido o padre. Fue entonces cuando más habitual fue el desempeño interino o en codirección de compañías, las más de la veces con acierto. Finalmente, desde ese año se extiende un prolongado periodo en el que encontramos actrices muy reconocidas que se dedican a la dirección. 
En este proceso España se muestra adelantada respecto a Europa, donde en algunos lugares como Inglaterra las mujeres debieron esperar a 1660 para poder subir a los escenarios. Plantea la autora que la mujer en el teatro español fue causa de su éxito, como se ha aceptado tradicionalmente, por la sensualidad que aporta en las comedias, pero reivindica que también por el acierto en la dirección de compañías. Romera Navarro (1934: 269) recordaba la existencia de una pragmática contra el lujo «De los trajes y vestidos, y uso de muebles y alhajas» (Novisima Recopilación, libro VI, título xiii, ley 1, págs. 267-270, la prohibición en Los Códigos españoles concordados y anotados. Madrid: Imprenta de la Publicidad, 1847-1851, 12 vols., T. 8, \$12, pág. 268) que comienza en 09.03.1534 pero es sancionada de nuevo, y posiblemente modificada, en varias ocasiones hasta 1623 en la que se extendía la prohibición de esa exhibición de riqueza "con los comediantes, hombres y mugeres, músicos, y las demás personas que asisten en las comedias para cantar y tañer, los cuales incurran en las mismas penas que cerca de esto están impuestas». No recoge más noticias posteriores, excepto la extraída de un archivo a 17.02.1557, que da cuenta del premio de cuatro ducados que se entregó en 1557 a una desconocida Beatriz "por lo que regocijó la Comedia del conde Palatino en el Abrojo", población cercana a Valladolid. La prohibición de 1586 fue la manifestación de esa preocupación moral que asalta después de Trento de la que habló en el cap. I.

Pese a las prohibiciones y las amenazas de multa y destierro, la reacción de las interesadas y los apoyos que concitaron demuestran la importancia que habían alcanzado ya en los escenarios. Secundariamente, también es prueba de cómo la imposición de la ortodoxia contrarreformista no tuvo el grado de cumplimiento que se observa en su contrapartida puritana, pues en Inglaterra y Holanda las mujeres fueron eficazmente desterradas de los escenarios.

Durante esos años los autores, propone Sanz Ayán, habían sido capaces de desarrollar recursos escénicos específicamente diseñados para sacar partido a la dimensión física de las actrices, elementos que, a pesar del escándalo que produjeron en teóricos y legisladores de la moral, contribuyeron al éxito del teatro comercial; no estoy seguro de que se pueda suponer que fueron ellas las creadoras de esos recursos, porque son autores y directores quienes escriben y arreglan los textos y diseñan la puesta en escena; pero el mérito que sí hay que atribuirles, posiblemente, sea el de su implicación en la administración de las incipientes empresas teatrales, en su fundación y mantenimiento, como propuso la autora (2009).

Las mujeres se incorporan al teatro como aprendizas en las compañías; la documentación conservada especifica que para aprender a cantar y bailar, por lo que su salario consistía en manutención, vestidos y sueldo. Es consecuencia de la proximidad a los gremios de las primeras compañías, que adoptaban su organización empresarial; no obstante, las mujeres tenían vetada su entrada en los gremios, por lo que hay que mirar con ojos nuevos la historia del trabajo femenino. La autora señala que posiblemente fueran objeto de discriminación salarial y de acoso, especialmente entre los poderosos, dados los casos conocidos 
de la esposa de Lope de Rueda y de Jerónima de Salcedo por el duque de Osuna. Además, las hijas y esposas también desempeñaron otras funciones, las primeras al participar en estrategias matrimoniales de sus padres al unirlas a actores de renombre y obtener así un vínculo reforzado y las segundas como corresponsables económicos junto con sus maridos de todas las operaciones de crédito que establecían al principio de cada temporada o como gestoras de todo el negocio en ausencia o fallecimiento de su cónyuge. En ocasiones su función resultó fundamental para su compañía y la evolución del teatro. Una situación especial era la de las hijas de autores y actrices; aunque no se conserva una documentación demasiado abundante, los autores parece que solicitaban licencia al Consejo arguyendo su necesidad, aunque el ejemplo que tiene es el de una niña de 8 ańos y solicita su empleo por cuatro.

En vista de todo esto, afirma que las mujeres comenzaron ser codirectoras y suplentes ocasionales ya en el XVI, aunque estudia los casos del XVII en los que cuenta con noticia directa y desecha los que proceden de inferencias de algunas afirmaciones o cuando simplemente son producto de la atribución de la profesión del marido a la mujer. La casuística habitual, en trece ocasiones, es la de haber compartido responsabilidades con sus maridos y haber asumido sus funciones a su muerte. Menos frecuente es la asunción ocasional tras el fallecimiento del cónyuge, seis casos, que estudia en el Anexo I (298-308), las autoras viudas. Con posterioridad, a partir de 1660, hay varias autoras de comedia de éxito, aunque no se habían eliminado las barreras legales que impedían la actividad laboral femenina; de hecho, a menudo se han formado en compañías en las que primero fueron actrices y después autoras de comedia. En este grupo recoge doce casos que revisa en el Anexo II (309-337). Al estudiar las biografías de este segundo grupo apunta que la dirección de la compañía no fue un substitutivo de unas tablas que se habrían visto obligadas a abandonar por el paso de los años, sino que fue el culmen de una carrera de actriz o la decisión meditada tras haber alcanzado un conocimiento profundo del negocio del teatro. Curiosamente, los datos apuntan a que las empresarias de más éxito fueron terceras damas en las compañías cuando eran jóvenes; recuérdese que la tercera dama solía estar encargada de los papeles musicales, tenía talento y desparpajo para ocupar escenarios y acaparar atenciones por sí sola, amén de que posiblemente fueran conocidas del público por sus actuaciones. Es sabido que las actrices españolas que triunfaron fuera de España fueron las que destacaban por sus aptitudes para el baile y el canto. No hay noticias que indiquen que estas compañías dirigidas por mujeres tuvieran un repertorio distinto al de las agrupaciones con un director masculino ni funcionasen de manera distinta.

Una de las principales virtudes del libro, ser una recopilación de textos previamente impresos dispersos en diversos estudios, es también uno de sus principales problemas: la ausencia de una puesta al día con los pertinentes materiales bibliográficos. Cierto es que la intención de la colección en la que aparece este estudio es la divulgación de la producción científica, pero dado que hoy en día 
la difusión digital permite la reproducción de trabajos previamente impresos, parece recomendable emplear el soporte del papel para fines más novedosos.

No abundan en modo alguno las erratas, aunque hay dos llamativas, como la que retrasó un siglo la construcción del Corral del Príncipe (63) o la que transforma un guirigay de aves de corral en un estruendo de pájaros cantores (69); en otra ocasión parece que el corrector ortográfico de un editor de textos ha sido el responsable de trocar las facecias humanistas en "fascículos humanistas» (84). También hubiera sido preferible emplear el mismo criterio en la modernización y transcripción de todas las entradas en el anexo donde reproduce y localiza los libros del inventario de la librería de Tomás de la Fuente (221-250).

Esas minucias no pueden hacer mella en sus grandes aciertos, como la conjunción de historia y literatura para abordar este teatro, su perspectiva comparatista o su dominio de la teoría y el metalenguaje de los estudios teatrales, su claridad expositiva y el hacer accesibles los especializados y muy actualizados conocimientos de historia y economía que posee. Su panorama de la dimensión económica de la actividad teatral en el reinado de Carlos II proporciona valiosísimos esquemas de interpretación con los que abordar otros periodos de nuestra historia teatral.

\section{Musas rameras}

Alejandro García Reidy

Las musas rameras. Oficio dramático y conciencia profesional en Lope de Vega Madrid-Frankfurt, Iberoamericana-Vervuert, 2013, 440 p. ISBN 978-84-84897-43-9

En estos tiempos de aproximaciones muy especializadas en Humanidades resulta una gran noticia que un joven investigador se atreva con un campo de estudios, más que un tema, tan complejo como el análisis de la figura del autor, la progresiva profesionalización de la dramaturgia barroca y la construcción de Lope como figura autorial. Semejante proyecto debe responder a una miríada de cuestiones desde ángulos múltiples y debería conllevar una comprensible y consecuente primacía de la enunciación de problemas sobre su resolución. No es el caso de esta monografía, que plantea cuestiones y establece soluciones con repetido acierto. García Reidy propone abordar el fenómeno minuciosamente, revisando y reinterpretando documentos que habían caído en el olvido y que recupera para extraerles sentidos novedosos, desde una perspectiva comparatista, necesariamente sucinta, con el desarrollo de la profesionalización del autor literario en Francia e Inglaterra. Prueba de su acierto no sólo es la buena recepción del libro, como dejan ver las elogiosas reseñas de Sánchez Hernández (2014), Kaufmant (2015) o Carreño (2015), sino también la atracción que continúa ejerciendo el tema de la construcción del autor dramático moderno fuera de 
nuestras fronteras, como aborda McCormick (2014) en su trabajo y otros autores que se mencionarán más adelante.

Dos cuestiones centran su atención: determinar las circunstancias históricas, económicas y culturales que explican por qué Lope es relacionado con los orígenes de la profesionalización del autor literario, así como en qué modo fueron cambiando las manifestaciones de su decisión de ser un escritor cuya vida es una mercancía más para sus consumidores. Con Bourdieu, García Reidy lo define como la génesis de un campo literario autónomo, es decir «la formación de una red de relaciones entre escritores organizada internamente por su poder en relación con el resto de integrantes del campo, el cual gozaba de una autonomía relativa por cuanto tan sólo estaba subordinado al campo del poder» (2013: 22). El propio sociólogo francés señalaba que el componente económico era una fundamental por articular una dicotomía entre escritores de éxito y escritores que no tenían el reconocimiento del público. Los segundos poseerían un campo de producción restringida y un gran capital específico, pero no tenían el éxito que alcanzaban los productores autónomos y de gran éxito económico o gran campo de producción.

Para abordar esta cuestión divide su trabajo en cinco secciones: una introducción al concepto de autor y la evolución hacia su profesionalización en la Europa moderna; a continuación examina las relaciones de los dramaturgos con sus interlocutores escénicos en el mercado peninsular del teatro en el Xvir. En la tercera sección se centra en establecer la importancia que tuvieron en la economía de Lope sus ingresos por su actividad teatral y sus efectos en su vida cotidiana, así como en su autopercepción autorial, que oscila entre el orgullo por sus creaciones y el deseo de trascenderlas, ascendiendo como era habitual en aquella cultura del privilegio, mediante el mecenazgo regio y/o nobiliario. Para denominarlo y situarlo en su contexto creo que se podría emplear el concepto de «mecenazgo diferenciado» de Lefevere (1997: 36-39) que utilicé para Lope (2009), en tanto que el éxito material procede del número de lectores/espectadores y el prestigio está vinculado a la inclusión del autor en el canon contemporáneo, posición que se obtiene del respeto de los clásicos, pero cambiando lo que sea preciso para satisfacer al lector/espectador, que es el nuevo mecenas. Finalmente examina la controversia de la publicación de sus comedias y su intento de continuar la explotación comercial, que le convierten en un antecedente español de lo que después se considera el embrión del derecho de propiedad intelectual.

En el primer capítulo (19-74) el autor aborda el análisis de la construcción de la autorrepresentación autorial de Lope, nacida de las diversas circunstancias históricas que delimitan en las que Lope construye una identidad social para alcanzar unos intereses específicos; en este tiempo se vacila entre si nace de un cierto valor de uso o de uno de cambio, de su reconocimiento por la nobleza y otros autores contemporáneos o por los consumidores. Es un momento en el que el éxito se mide por la incorporación a un canon contemporáneo, un capital simbólico que determinaba la posición de su posesor en el seno del campo por el 
reconocimiento de los demás miembros del campo, que García Reidy relaciona con la institucionalización de la literatura en academias literarias y la agrupación de escritores en cenáculos constituidos por afinidades artísticas, así como por la capacidad de influir en la política de sus contemporáneos y en la progresiva canonización literaria. En esta sección se podría haber introducido la existencia de estrategias y procesos de autocanonización coetáneos — revisados entre otros por Ruiz Pérez (2004), García Aguilar (2005) o Álvarez Amor (2008) — al hilo de la referencia a una dicotomía clientelismo/mecenazgo en la que se oponen ambas formas de relación por la existencia de un reconocimiento artístico en el segundo caso; me pregunto si en el primero no debiera haber una valoración semejante para explicar esa protección.

Lope transmutó su periplo vital en literatura, amoldándolo a las circunstancias que atravesaba, como otros artistas en el mundo moderno que persiguen forjar su identidad; como es sabido, fue a fines de la Edad Media cuando la literatura de entretenimiento se insertó en el mercado literario, sin abandonar el mecenazgo nobiliario como vía de obtención de un anhelado prestigio. Como señala García Reidy, es muy indicativo que el autor fuera antes responsable penal de su obra que propietario de los beneficios que se derivaran de su impresión y venta, ya que el privilegio de publicación que se obtenía de la autoridad competente, la propiedad legal, se vendía consuetudinariamente a un impresor, que corría con los gastos de impresión y distribución del libro, lo que implicaba la pérdida de cualquier derecho sobre el texto. Ni que decirse tiene que este sistema fue concebido como un mecanismo legal para controlar la impresión de obras y la publicación sin privilegio de impresores sin escrúpulos; en definitiva, la legislación protegía los intereses del reino y de la naciente industria editorial, sin cuidar en lo más mínimo del autor y sus derechos.

Los siguientes capítulos abordan la profesionalización de la escritura, con especial atención a las condiciones socioeconómicas que determinaban el espacio literario, y el grado de desarrollo del mercado que otorgaba valor económico a las obras literarias. El concepto de profesionalización está ligado al desarrollo de una idea moderna de una conciencia autorial, expresada en la imagen que los autores proyectan de sí mismos. Finalmente, estas nociones están ligadas a la consideración social que reciben los autores, que se manifestaría en el reconocimiento de la propiedad intelectual.

Esboza en el segundo capítulo (75-166) el entramado socioeconómico del teatro del siglo Xvi, con el paso de la dependencia del mecenazgo a la aparición de compañías profesionales que satisfacían la demanda de los nuevos espectadores urbanos. Su análisis aborda únicamente el teatro profano representado en ambientes laicos, dejando de lado otras formas dramáticas coetáneas, con las que no comparte una de las consecuencias de este cambio: que el texto alcanzase autonomía para convertirse en centro de la representación aislado del contexto, lo cual sólo se puede referir a un tipo de texto escrito para la representación en el corral, pues las comedias genealógicas, ahora revisadas por Zugasti (2013), o las 
piezas hagiográficas que Lope escribió no se pueden englobar en este grupo. Por otra parte, si bien la mercantilización del teatro lo llevó a ser un negocio institucionalizado, tal condición está lejos de ser una aventura de libre empresa, puesto que los autores se deben someter al dictado de quienes son sus patronos y afrontar la omnipresente y muy diversa censura difusa de la que habla Vega Ramos (2013).

La mercantilización del teatro español coincide con un fenómeno similar londinense de los años 60-70; los teatros se convirtieron en punto de encuentro para diversos tipos de socialización que iban desde la actividad comercial a la de establecimiento del horizonte de modas y comportamientos. Una capitalización del ocio que no sólo incluía diversión, sino también integración en grupos y reconocimiento sociales. Este desarrollo del mercado dramático trajo una curiosa especialización: la de la escritura de obras con vistas a su representación por una compañía concreta poseedora de ciertos activos para los cuales se escribe específicamente. Los actores cobran así una función de intermediación comercial y artística que no tuvieron al principio del proceso, cuando eran también escritores. Ciertamente, esa doble condición no desapareció en España con el paso del tiempo, porque se conserva noticia de 29 autores-actores; en Inglaterra, en cambio, no dejó de ser frecuente. Claro que la exigencia de los lectores les obligó a aumentar su repertorio más allá de la producción propia, lo que impulsó la aparición de escritores dedicados a este menester de escribir para permitir la representación en los años 70-80 del XvI.

Las compañías profesionales se convirtieron en los principales clientes de los dramaturgos, especialmente en el periodo en que quiere analizar el principio de la actividad dramática de Lope y en su etapa final, entre 1580 y 1620. Reconstruye el proceso de venta de una comedia a un autor de comedias, la firma de una serie de documentos que convertían el acuerdo privado en un acto público que comprometía a las partes; con él, se fijaba el valor económico de la obra y se transfería su propiedad al autor de comedias. El dinero, claro, pagado a cada escritor variaba. La cantidad no dependía del éxito del texto, que no estaba garantizado aun cuando fuera de gran calidad, pues el público era quien tenía la última palabra. Algunos escritores tuvieran capacidad de decisión sobre la puesta en escena; aunque la legislación impedía la asistencia a los ensayos de personas ajenas al montaje, parece que los poetas también podían comprobar de primera mano las decisiones del autor de comedias y, posiblemente, influir en algún modo sobre ellas, aunque no fuera muy habitual. Probablemente, la capacidad de influencia sobre las decisiones del autor de comedias estuviera en relación directamente proporcional al reconocimiento que tuviera en su momento el escritor. La calidad de un texto no aseguraba su éxito comercial, pues el triunfo se relacionaba por lo general más con la puesta en escena, bien por su excelencia, bien por decantarse el público por una compañía por cuestiones de varia índole, en detrimento de obras de mayor calidad.

La relación de poetas y actores era un hecho y Lope se había convertido en el favorito de actores y público; Cervantes encuentra que es culpa de ese factor eco- 
nómico la degradación de su calidad, como señala en varios lugares de su obra. No hay noticia de cómo trabó relación con el mercado teatral y las estrategias que adoptó para relacionarse con las compañías que representaban en Madrid en 1579-1583. García Reidy supone que hubo de tener comienzo en torno a 1581, tras dejar sus estudios en Alcalá, o 1583, con mayor probabilidad, cuando regresa de la expedición a la isla Terceira. Tal vez sus primeras comedias las estrenara Jerónimo Velázquez, autor de comedias de éxito con el que Lope mantuvo alguna relación laboral, amén de la conocida, de tipo sentimental, con su hija.

Su fama a esas alturas le viene de su escritura de romances moriscos; su paso al teatro pudo tener que ver con la localización de la corte en Madrid, el incremento de su población y la construcción de dos teatros en la década de los 80 . En el conocido proceso por injurias Lope se presenta como un mero aficionado a la escritura de textos teatrales, por entretenimiento, aunque reconoce que algunas ya han sido representadas por Velázquez y otros; Lope, indicativamente, arguye en su defensa, puesto que no podía reconocer la causa de la escritura de los libelos, que la enemistad con Velázquez nació de haber dejado de entregarle sus comedias para dárselas a Gaspar de Porres, lo que de nuevo parece apuntar a que estaba trabajando ya entonces como dramaturgo. Aunque hay dudas por la falta de testimonios fechables con seguridad, parece cierto que Lope comenzó su actividad dramática sostenida en la capital del Turia y después la continuó en Alba en 1591-1595. Los datos recogidos en el diccionario de Ferrer Valls (2008) permiten atisbar sus contactos con distintos autores a quienes vende simultáneamente diferentes comedias.

Además, Lope escribe autos sacramentales. Pérez de Montalbán afirmaba que escribió más de 400, aunque hoy sólo conservamos media centena. El negocio con los autos sacramentales estaba garantizado para los escritores, porque las autoridades solicitaban autos nuevos cada año, amén de ser unas festividades muy cuidadas en todos los aspectos de su puesta en escena. El prestigio en este caso era social, porque las autoridades políticas y religiosas estaban muy implicadas en aquellos festejos y representaciones. Evidentemente, García Reidy no pudo consultar los estudios de Izquierdo Domingo (2013a y 2013b), que recogen valiosas noticias sobre los autos escritos por Lope y sus contextos. Los autos incluso podían teñirse de contenido político, a pesar de su naturaleza eucarística; Lope lo hizo con motivo de las bodas reales de 1599 (138).

En otras ocasiones Lope escribe por encargo, como otros autores de su época. Aunque la documentación no es muy abundante, conocemos piezas escritas para una celebración nupcial, la defensa de intereses personales de un noble o con la esperanza de conseguir el mecenazgo o la aprobación de los destinatarios, aunque a veces sin éxito. Un capítulo aparte lo constituían las representaciones en Palacio donde los autores de comedias llevaban no sólo obras escritas específicamente para ese público y espacio, sino también textos que figuraban en el repertorio habitual de la compañía. Lope comenzó a producir para la corte alrededor de 1596 con su comedia mitológica Adonis y Venus, que pudo ser 
representada por nobles, según se deja ver en la introducción a la Parte XVI de 1622 y la última sería El amor enamorado (1633), para la inauguración del Palacio del Buen Retiro; incluso llegó a escribir comedias sobre temas solicitados por miembros de la corte, cuya puesta en escena supervisó. En otras ocasiones tuvo encargos puntuales de otras instituciones públicas o privadas: Canonizaciones de santos patronos, en particular; de hecho, es muy probable que sus obras hagiográficas fueran el producto de encargos específicos.

En el tercer capítulo (167-200) analiza los ingresos del autor. Aunque sus ganancias estaban vinculadas al mercado literario, también contaba con las mercedes y regalos de protectores nobles o la Corona, amén de sus rentas como eclesiástico y algún otro ingreso extraordinario. A partir de las cantidades que Pérez de Montalbán supone que Lope ganó en vida, realiza un estudio minucioso de la cronología de su producción dramática. Según los datos que recopila, Lope habría escrito en torno a 12 comedias al año la mayor parte de su vida, y por ella obtendría dos tercios de sus ingresos totales, a lo que habría que sumarle la obtenida de la venta de sus autos sacramentales, una cantidad menor, sin olvidar que a ello habría que añadir cuanto obtuvo de la venta de los privilegios de impresión. Es difícil estimar la cuantía por la falta de documentación, aunque sabemos que la venta de privilegios de las partes vII y viII de comedias de Lope reportó al mercader Francisco de Ávila al vendérselas a Miguel de Siles, impresor madrileño, 80 ducados por volumen. Algunos otros volúmenes pudieron proporcionarle más ingresos, porque sabemos que algunos autores de éxito consiguieron más de cien ducados por sus publicaciones. Por todo ello, y suponiendo que las 14 partes le proporcionaran siempre 80 ducados cada una, a los que habría que sumar los 17 volúmenes diversos que publicó por los que tal vez obtuvo 100 ducados, le habrían proporcionado casi 3000 ducados. A esas cantidades habría que añadir otras que le proporcionarían actividades extraordinarias, como los 300 ducados que le abonó en 1620 el Ayuntamiento de Madrid por la escritura de las celebraciones de la canonización de San Isidro Labrador. Además, Lope recibiría dádivas y dinero de sus protectores y sus mecenas, nobles y regios, cuyas finanzas estudia, en cantidad variable. Un capítulo aparte es el de las varias rentas eclesiásticas que percibe, cuya cantidad le proporciona anualmente al final de su vida aproximadamente 1200 ducados anuales. Finalmente, ingresó algunas cantidades importantes con la dote y el fallecimiento de sus esposas.

Con estos ingresos Lope tuvo una vida cómoda en el plano económico, especialmente entre 1601 a 1605, cuando pudo prescindir de estar al servicio de noble alguno gracias a la alta rentabilidad de sus creaciones dramáticas, aunque también pudo ser producto de haber seguido a Andalucía a Micaela de Luján en 1602, tras conocerla en 1599, dejando a su familia en Toledo, lo cual sólo podría hacer si tenía esa independencia económica, que le permitiría mantener a dos familias. Sus gastos, amén de algunos sobresalientes como la adquisición de la casa en la calle de Francos, son bastante desconocidos aunque parece, por sus testamentos, que no contrajo grandes deudas. 
En definitiva, Lope tuvo una buena posición económica merced a sus ingresos como escritor. Si hemos de hacer caso a Pérez de Montalbán, sus ingresos como creador literario eran cuatro veces superiores a los que obtuvo de dádivas y obsequios nobiliarios.

Con el siguiente capítulo, el cuarto (201-300), García Reidy se introduce en el concepto que tiene el autor de sí mismo en cuanto escritor, a través de diferentes tipos de documentos, desde cartas personales a prólogos de obras impresas. Su longitud habla de la importancia que le concede su autor, que de hecho toma el título de su libro de unos de los documentos que maneja, una carta de Lope de 1620 a Sessa, aunque se trata de un tópico de recorrido mayor en su obra, como recuerda Carreño (2015: 199). En esos textos epistolares el autor reflexiona sobre su propia escritura, su posición en la sociedad y su relación con otros como él. Tras de esas realidades se encuentra la aparición y consolidación de la conciencia profesional; de ella surge una intencionalidad autorial, que es: «La motivación que lleva al escritor, en cuanto miembro del campo literario y del social, a producir sus textos con vistas a lograr un determinado efecto en sus lectores que repercuta en la imagen que se tiene [de] él» (García Reidy 1993: 202). Este apartado aborda la revisión de estos materiales en el contexto del autor y sus aspiraciones, expresadas por sus textos poéticos; actualmente, se insiste en la necesidad de abordar el estudio de su producción literaria globalmente, como un itinerario de las metas literarias y/o sociales que se fue marcando Lope y en el que algunas de sus afirmaciones tienen un alcance distinto al que pudieran tener en su periodo de senectute. Tal vez, de la gigantesca bibliografía existente se podrían haber empleado los estudios de Carreño que acompañan a los textos de Lope (1998, 2004, 2007 ó 2014) o los de Pedraza Jiménez (2002) y (2008) para acotar más el contexto. Como el propio autor apunta más adelante: «El discurso del Fénix no fue en absoluto homogéneo. Lope fue un escritor complejo en sus escritos, incluso contradictorio, y por ello plenamente hijo de su época, por cuanto encarnó como pocos la escisión que se estaba produciendo en el campo literario español entre las circunstancias económicas reales y el imaginario colectivo heredado [...] nunca llegó a defender plenamente la profesionalización como un modo de vida legítimo y tan prestigioso como el mecenazgo» (299).

Comienza con el estudio de las referencias que Lope hace a su obra en el epistolario privado con el de Sessa, en el que introduce, en busca de la diversidad que siempre entretiene, algunas escuetas referencias a la conciencia de su condición de escritor, aunque a menudo teñidas por su condición de estrategia para alcanzar algún regalo. La hipótesis que desarrollé sobre la importancia del ascenso social para los autores de fines del Xvi (2013: 96-97) es aplicable a Lope, al menos en parte. En el fondo, sus cartas representan, como sucede en el juicio por calumnias de 1588 , la dicotomía en la que se debaten los primeros escritores profesionales: la imagen que quieren ofrecer de sí mismos - creadores sin objetivos crematísticos y ligados a la nobleza - y la realidad — receptores anhelantes de beneficios por sus textos- Era una cuestión ideológica y social, el escritor 
reproducía el modelo nobiliario del universo del privilegio, por lo que debía obtener su bienestar de la fuente de los mismos, el cabeza de la corte; esa misma sociedad vertical es la que querían abrazar los autores.

Ciertamente, el imaginario barroco presenta a los escritores como carentes de oficio y beneficio. El autor propone que se trata de una crítica nacida de los propios escritores contra aquellos que no se encontraban en el canon ni protegidos por la nobleza, esto es, aquellos cuya actividad creadora se orientaba específicamente hacia el mercado literario y unos empresarios alejados, por antonomasia, de una nobleza que mira con desprecio cualquier oficio comercial remunerado. La poesía era sólo admirada si no se vivía de ella. Aunque las estrategias tradicionales de legitimación social ya no servían para Lope y otros que se dedicaban a la creación literaria, continuaron recurriendo a ellas. Volvieron sus ojos a la Antigüedad clásica, en la que encontraron modelos literarios y/o vitales con los que justificar sus propias trayectorias literarias. Lope recurre a Virgilio como modelo óptimo de autor de la antigüedad y de las relaciones que el principal poeta del imperio debía y podía mantener con el poder, algo habitual en la mitología autorial en occidente, incluso ya en tiempos de Juan del Encina. En ese perfil sobresalía la doble vertiente de la protección del poeta: el mecenazgo de un noble Mecenas y el apoyo de Augusto, pero tal ideal no se correspondía con la España contemporánea. La protección nobiliaria no tenía correlato real: sólo 25 de unos 2000 autores disfrutaron de algún empleo procedente de un noble o directamente de la Corona, lo cual es indicio de la competencia que había para acceder a esos puestos. Los siete protectores con los que contó a lo largo de su vida son una muestra del escaso rendimiento que obtuvo de su relación con ellos.

Paralelamente a estas aspiraciones, Lope apostó fuerte por erigirse en poeta cortesano, para lo cual no duda en ocultar su escritura dramática, por su negativamente juzgada dimensión crematística. De ser un poeta popular, difundido por vía manuscrita o en antologías, en sus primeros veinte años, pasó a fines del XVI a perseguir un nuevo capital simbólico, como poeta cortesano y docto. $\mathrm{Si}$ el éxito en el corral le había dado el favor del público, su prestigio en cambio no había crecido entre los eruditos, que consideraban el teatro, en concreto la comedia, como un arte menor, en general.

El declive de Felipe II y las expectativas de transformaciones importantes que vendrían de la mano de un nuevo monarca indujeron a prepararse para el cambio a nobles y artistas. La facción aristocrática del marqués de Denia veía la posibilidad de ocupar espacios de poder que dejase la oligarquía que se retiraba con el monarca prudente, unos cambios políticos que afectarían a ámbitos culturales y literarios. En ese nuevo escenario la nobleza precisaría de una vitola cultural de protección de las artes por vía del mecenazgo que proporcionaría grandes oportunidades a literatos y poetas. Lope percibió tempranamente los cambios en lontananza a mediados de la década de los 90 y comenzó su preparación para aspirar a alcanzar una buena posición e incluso la protección del 
propio monarca. En esta sección tal vez podría haber reforzado el correcto contexto histórico que esboza con Tropé (2010) o Enciso Alonso-Muñumer (2001 y 2008). Al final de su destierro en Madrid, y sin dejar de escribir comedias, Lope se lanza a obtener el reconocimiento de poeta docto y cortesano. En 18 meses saca tres libros que pertenecían a lo más selecto de los tipos de texto literario, tres textos relacionados con el uso literario virgiliano, la Arcadia, dirigida al duque de Osuna, que se encuentra en la órbita bucólica, y el Isidro, dirigido al cabildo de la ciudad, y la Dragontea a Felipe III, en la épica. Con ellos quería situarse en la cumbre del Parnaso español y atraer la atención del monarca, posiblemente con la intención de convertirse en el poeta por antonomasia del reino. Empleó todas las posibilidades de autopromoción que le ofrecía la imprenta y silenció el prestigio ganado, el capital simbólico, con aquellas obras dramáticas que aún no ostentaban el mismo valor que otros tipos de texto reconocidos por la tradición. Sólo alardearía de ellas, recuerda más adelante el autor (279), cuando comenzó a encargarse de la publicación de sus comedias, entre 1609 y 1624, en los paratextos de los 12 volúmenes que se imprimen bajo su control.

Además, Lope empleó otro sistema de promoción, la participación y dirección de justas poéticas. En 1605 el cabildo toledano le encomendó el cartel de la Justa, la oración poética inaugural y posiblemente la recopilación de materiales literarios para la publicación; el cartel, en endecasílabos sueltos, se recogió en su póstuma La vega del Parnaso. No es sólo un panegírico a futuro del monarca, ya que es también una autoalabanza y una defensa de la utilidad pública de su trabajo poético. Las razones de la alabanza de las letras tienen un componente utilitario, son archivo de la memoria, mecanismo de conservación y conocimiento de las leyes, repositorio del conocimiento humano; de ahí que recoja una relación de dirigentes y héroes cuya memoria perdura gracias a la intermediación de los poetas, entre los que destaca a Augusto y Virgilio, con quien se identifica.

Aunque no quisiera sacar a relucir su faceta de creador dramático en sus maniobras para conseguir el ascenso social, el mundo editorial se ocuparía en obligarle a salir del anonimato autoimpuesto con la aparición en 1603 del volumen Seis comedias de Lope de Vega Carpio y de otros autores. A ese impreso espurio se refiere en el prólogo de El peregrino en su patria, donde no deja de mostrarse orgulloso de la popularidad y aceptación de su teatro, pese a su heterodoxia, que llega incluso no sólo a otros países como Portugal, Italia o Francia, sino incluso a otros continentes. Pero esa apología de su teatro tiene como razón de ser denunciar las atribuciones erróneas del impreso Seis comedias; por ello recopila la conocida nómina de títulos.

En su Arte nuevo su desobediencia a los preceptos clásicos se explica porque el cumplimiento de la preceptiva le granjearía el predicamento de quienes conocen y suscriben los valores de la poética clásica, pero no la "fama y galardón» del pueblo; ni siquiera el mecenazgo forma parte de esa fórmula del éxito, llamativamente. El favor del público se ha convertido en el nuevo factor determinante por lo que es justo conseguir satisfacer su gusto. Tal vez había sido útil tener en 
cuenta las reflexiones de Maestro (1998) sobre el vulgo para percibir que no renunciaba con su teatro a satisfacer a ningún sector de sus posibles espectadores. De hecho, en los prólogos de sus partes de comedias, reflexiona sobre estas cuestiones y otras de literatura y, en especial, teatro. Su carácter híbrido, entre ensayo y ficción, le permitía incluir en ellos discursos con los que transmitir una proyección de sí mismo, defenderse de sus enemigos literarios o construir razonamientos sobre sus ideas estéticas. No fue precisamente original, porque tenía ilustres precedentes en el prólogo de Cervantes a sus Ocho comedias y ocho entremeses nuevos (1615) y el Apologético de las comedias españolas de Ricardo de Turia, incluido como preliminar en su Norte de poesía española (1616).

Otro grupo de reflexiones son sus intentos de dignificación social de los autores dramáticos, a los que presenta con una sólida formación académica y moral prístina en varios lugares, aunque no puede dejar de reconocer que quienes escriben para el teatro a menudo no son precisamente eruditos.

Una nueva etapa, el periodo de senectucte, iniciado en 1624, supone que Lope redoble esfuerzos con la entronización del nuevo rey para alcanzar el apoyo que se le había resistido anteriormente. Lo que solicita, expresamente en 1629, es un puesto de cronista real; pero el nuevo valido protege autores andaluces y la plaza que Lope pretendía se concede al joven historiador Pellicer de Tovar.

En el capítulo quinto (301-390) Reidy aborda el proceso de la reapropiación autorial de su teatro (301). Aunque los derechos de autor fueron ajenos a la práctica literaria del XvII, por cuanto carecían de un andamiaje legal que los respaldara, fue entonces cuando surgen al hilo de prácticas y discursos relacionados con la mercantilización de la literatura. Algunos dramaturgos, como Lope, participaron en la puesta en circulación de sus textos, y para ellos se aprestaron a llevar a cabo procesos de controlar el uso de su propia obra mediante diversas estrategias legales, discursivas y pragmáticas que le permitieran recuperarla. Ni Lope, ni ningún otro dramaturgo expresaron objeción alguna contra este esquema de propiedad y venta durante largos años; el cambio de actitud del Fénix se produjo cuando persigue proyectar una imagen de poeta docto y decide que las comedias contribuyan a ello. Al otorgar a su teatro la misma consideración que a otros tipos de texto privilegiados por la tradición literaria, estaba impulsando decisivamente la profesionalización del escritor y su entrada en el mundo moderno. Lo lleva a cabo, por ejemplo, en 1620, en la Parte XIV, al hablar del carácter retórico de su teatro por su capacidad para causar impresión, rápida y eficaz, en el público de los corrales. Un año más tarde (1621) en la epístola poética que dirige a don Diego Félix Quijada y Riquelme en La Filomena, aunque reconoce el valor literario de las comedias escritas para la escena, apunta que «la calidad de sus virtudes retóricas y figuras conceptuales» no puede ser degustada por una parte del público que carece de la formación suficiente para apreciar sus virtudes (Obras poéticas, 780, vv. 16-21), una desconfianza en el público que aparece de nuevo en el prólogo de la Parte XVI (1621). Con afirmaciones como éstas, en las que se pondera el valor poético y retórico del teatro, el autor propone como técnica de lectura la 
del letrado, común en los siglos XVI y XVII, que analiza los loci communes; con ello estaría impulsando a los lectores a tomar de sus textos fórmulas, citas y sentencias que se transformarían en lugares comunes y podrían emplearse en sus escritos, una estrategia que algunas ediciones, en el mundo anglosajón, reforzaban con marcas tipográficas orientativas para el lector de pasajes o verbos, que los aproximarían a entrar en la categoría de las sententiae. Lope recomienda esta forma de leer sus textos la intención de insertarse en un canon de escritores coetáneos; por eso, no es extraño que a partir de 1614 adquiera otra función: la de atacar a Góngora y sus seguidores de la nueva poesía. Desde los preliminares de la Parte XIII a la Parte $X V$ o los prólogos que abren algunas comedias comienzan a aparecer las invectivas contra aquellos cultistas.

Insiste, como Pérez de Montalbán y Cervantes, en que su lectura, y no la asistencia a la representación, proporciona al receptor sensaciones e informaciones que a menudo se ven dificultadas por problemas que también afectan a la recepción e impiden disfrutar de la obra: el público asistente, con varios ejemplos muy meditados, y la no siempre acertada labor de mediación que supone el trabajo del actor. No obstante, la lectura del teatro genera desasosiego en los escritores por permitir que se someta su obra a un escrutinio minucioso, la «censura de los aposentos» de la que habla Lope, que deje ver sus errores, que el Fénix explica en ocasiones como producto de la rapidez con la que tiene que escribir. Además, con la lectura no se puede apreciar el sentido y posibilidades que da la representación, pues no se pueden actualizar todos los signos que contribuyen a crear una representación, la espesura de signos y sensaciones de la que habló Barthes. Esa reticencia hacia la página impresa como medio de difusión del teatro es moneda corriente en Europa, desde Molière al inglés John Marston, pero ya en 1618 Lope empieza a diseminar en los prólogos de las Partes consideraciones acerca de sus beneficios; se percibe incluso en el cambio del ordenamiento del repertorio de comedias que integra en El peregrino: En 1604 se estructura por la yuxtaposición de repertorios de compañías a las que había vendido sus textos, mientras en la edición de 1618 lo hace de acuerdo con las obras reunidas en las partes de comedias publicadas hasta entonces.

Como es sabido, este proceso nace la reacción de Lope ante la publicación del volumen lisboeta Seis comedias, que desata su proceso de reapropiación autorial; la aparición de otras compilaciones de sus comedias en Zaragoza produjo solamente una queja en la epístola que le escribió a su amigo Gaspar de Barrientos y que recoge en las Rimas (1604) (vv. 184-186 y 199-201) por la mala calidad de la edición, que incluía como suyos numerosos fragmentos que no lo eran. A la zaga de este impreso zaragozano, que tuvo varias reimpresiones, Alonso Pérez, ya célebre editor en la Corte, se lanza a sacar en 1609, tras unos años de negación de licencias para la publicación de libros de entretenimiento en la Corte, un libro en cuarto con doce comedias, con lo que adoptaba e imponía un formato editorial y de contenido. En 1614 Lope hizo frente a la amenaza para sus intereses con su implicación en la aparición de la Parte IV. Fue el autor de comedias Gaspar de Porres quien 
se ocupó de los trámites burocráticos del volumen, dedicado al duque de Sessa con una epístola que realmente fue compuesta por Lope, como sabemos por el manuscrito autógrafo. A través de Porres, Lope justifica la publicación de sus obras de manera un tanto tópica. Gaspar de Porres dice imprimirlas como respuesta a la apropiación por parte de terceros de unos textos que imprimieron, además, con graves deturpaciones, que puede corregir por poseer los originales, y a menudo sin respetar ni siquiera la debida atribución a su autor.

Pero el empleo de terceros para hacer su trabajo no tenía visos de ser efectivo, por lo que Lope recurre a la reclamación legal para defender el control de sus publicaciones. Aunque otros autores también se quejaron de la suerte de sus obras en la imprenta, Lope fue el único que buscó que se establecieran unos límites a la manipulación que cualquiera podía hacer en la impresión sin licencia con sus obras, lo que García Reidy interpreta como su voluntad de que se reconocieran sus derechos de autor sobre su producción artística. El primer intento fue un memorial, sin fecha pero de hacia 1610-1611, que presenta ante Felipe III; su planteamiento es que hay «unas prácticas que dañan el honor de los poetas y, por extensión, el del conjunto de la nación española». Las quejas de Lope mezclan su interés privado con el público y nacen no de una reivindicación del reconocimiento profesional del autor literario, sino de una concepción derivada del código social imperante en el siglo Xvir. Las prácticas que denuncia Lope son dos: la venta ambulante de relaciones de comedias y obras en formatos de consumo, los pliegos sueltos, que además son cantados por ciegos y pobretones que deturpan sus textos y ponen en su boca lo que nunca dijo. No hay constancia de que produjera ningún efecto este memorial, y por eso tal vez retoma estas críticas en obras posteriores; incluso pretendió, en un pleito en 1616 con Francisco de Ávila, impedir que éste obtuviese permiso para imprimir dos nuevas partes de comedias. De nuevo, Lope no pretende que se le reconozcan unos derechos sobre sus obras, sino, como en el caso anterior, reivindicar su nombre por su empleo indebido como reclamo comercial y evitar el mal traslado de sus textos. La respuesta de Ávila fue que esas comedias eran de Lope, como podía probar porque las había vendido y entregaba, con su firma, la cesión de los derechos de los manuscritos para que pudieran ser impresas. La justicia dio la razón al editor, un varapalo que llevó a Lope a encargarse él mismo de la compilación y publicación de sus obras, algo en lo que también pudo influir la iniciativa de algunos autores como Virués en 1609 y Cervantes en 1615 de publicar sus textos teatrales. Así salió en verano de 1617 la Parte IX, con la que frenó la edición de sus textos dramáticos a manos de otros impresores durante veinte ańos, a lo que pudo ayudar que los autores de comedias preferían revendérselas a Lope y estar en buena relación con él.

Aunque no eliminó completamente la aparición de copias ilegales o marginales, las partes extravagantes, la reapropiación autorial fue un hecho. En diversos lugares de su obra Lope fue diseminando su concepto de la propiedad literaria y de la relación del autor con su obra, desde el soneto prologal de sus 
Rimas (1602), «Versos de amor, conceptos esparcidos», a dedicatorias de comedias. Emplea imágenes diversas para corporeizar tal vinculación, como la del padre con el hijo, como en la dedicatoria de Santiago el verde (Parte XIII); o en la dedicatoria de Los muertos vivos al dramaturgo Damián Salucio del Poyo, donde las obras se transforma en hijos pródigos, cuya vuelta celebra aunque le resulte casi imposible devolverlo a la pureza original, una deturpación de reparación imposible, como la de soldados, en El dómine Lucas, que regresan desfigurados por el combate. Los responsables de estos destrozos son todas las secciones de la cadena de transmisión, legal e irregular, de textos del mundo áureo, desde impresores a libreros, pasando por memoriones, ciegos y vendedores de pliegos, un problema de extensión europea, como señala. Con todo, esa reivindicación no se vio acompañada de un trabajo minucioso en la edición; nunca proyectó volver a sacar a la luz corregidas las comedias que primero aparecieron fuera de su control, salvo a principios de 1635, cuando por el levantamiento de la prohibición de publicar novelas y comedias Lope obtuvo licencia para dos volúmenes de comedias. El primero sería la Parte XXI que apareció aquel año, mientras que el segundo, con doce comedias, sería otra parte que nunca llegó a la imprenta.

La monografía de García Reidy contiene escasísimos errores tipográficos y bibliográficos, por lo que cito los que he localizado tras una lectura minuciosa. Son tan pocos como la mala cita de [Aragone] Terni (1971) de la página 163, nota 228 en la bibliografía final. Le pasa lo mismo en 211 y 409, donde se confunde el nombre Gerard con el apellido Cheney, o en 218 y 423 el apellido con el nombre Shepard, Sanford. En una ocasión se denomina Martínez Jiménez (2006) (312) a Martín Jiménez (417) y en 328, n. 66, se le cambia el nombre al librero Antonio Noguera por Alberto Noguera

La minuciosidad y la selección que presiden la búsqueda de evidencias, la claridad del estilo expositivo, el cuidado mencionado de la presentación de la información y el orden de construcción de sus análisis y reflexiones son un deleite para el lector. Su trabajo, por primera obra que sea, es ya instrumento imprescindible para la comprensión de la figura de Lope de Vega.

\section{Identidad personal y nacional en Lope}

Antonio Cortijo Ocaña

La porfí: identidad personal y nacional en Lope de Vega

Barcelona, Anthropos, 2013, 253 p.

ISBN 978-84-15260-59-2

El siguiente texto cuya revisión propongo en este artículo es un minucioso análisis y recopilación de la porfía y, especialmente, del contexto político e ideológico en el que surge, no sólo en cuanto lugar común empleado por una miríada de textos de la Edad Media al siglo XviI reunidos por el autor, sino también como esencia teórica nacional que encarnaba el arrojo militar, la fe religiosa y el em- 
puje tenaz del enamorado por antonomasia y sus usos en la construcción de una identidad nacional basada en una ideología; en ella son elementos importantes tanto para construir una mitología de los orígenes como para la propaganda que difunde insistentemente entre los súbditos esa identidad, función que desempeñan las otras obras dramáticas analizadas. A la condición de ingrediente central de largo recorrido de la constitución de la emotividad de un grupo humano que tuvo la porfía se le superpuso la función de responder a un ataque programado y constante contra la historia y esencias españolas a manos de cronistas y propagandistas extranjeros, la denominada leyenda negra, un capítulo complicado donde los haya de la historia moderna, en el que adentra desde la lectura de fuentes directas y sin dejarse guiar ciegamente por la crítica ni en un sentido ni en otro. Para el autor, Lope realiza una suerte de traslatio desde lo personal hacia el plano político/nacional, idea muy interesante que tal vez debiera haber sido sustentada con una base empírica mayor, dada la abundancia de textos susceptibles de ser aducidos en ese sentido.

Este libro es producto de la confluencia de varias líneas de trabajo que el autor ha ido explorando a lo largo de los últimos años, lo que se manifiesta en la magnitud de los datos que maneja y en el empleo y disposición de conceptos previamente explorados y ensamblados, lo que en ocasiones produce la sensación, pasajera, de que construye su discurso por yuxtaposición de bloques que el lector debe interconectar para captar el riquísimo panorama compuesto. No puede ser de otro modo, dado que Cortijo Ocaña construye su argumentación con tanta minuciosidad en la recopilación de datos como autonomía y creatividad en su análisis. Este libro es una reunión de intereses y materiales diversos, que comenzó con su edición de Porfiar hasta morir (2004), donde estudiaba a Macías y prosiguió con la edición de textos de Mendoza (2008) y Coloma (2010) que le orientan hacia su edición de Los españoles en Flandes (2014), y sospecho, y espero, que se complementa además con materiales de otro estudio que tiene en preparación sobre las operaciones propagandísticas antiespañolas de Inglaterra en este periodo, del que supongo he encontrado una muestra reciente (2014).

Pero el inicio del estudio es el personaje literario de Macías, cumbre de la lírica, cancioneril y petrarquista, y de la prosa, con su transformación en la ficción sentimental, nacida del cuestionamiento del amor cortés y del choque entre realidad y deseo en un tiempo de crisis, como lo denomina; el análisis de su transformación se desarrolla en alguna de las páginas más brillantes del libro (15-passim). A ese momento pertenece Sebastián Fox Morcillo, uno de los más reputados hombres de letras del continente en su tiempo, cuya dedicación política se echa de ver en su concepto tacitista de la Historia, que considera la disciplina por antonomasia, como herramienta de la gobernación del Estado. El estudio de su obra y figura ilumina el abordaje de sendos historiadores de Flandes, Bernardino de Mendoza (2008) y Carlos Coloma de Saa (2010), embajadores a fines del xvi y en el primer tercio del xvir que practicaron ese compromiso que pregonaba Morcillo. A través de su estudio apreció el desasosiego de ambos ante 
la campaña de desprestigio en Europa contra España, lo que le llevó al estudio de la leyenda negra y la construcción de la imagen de nación entre 1550-1650. Después con la preparación de la edición de Los españoles en Flandes (2014) se adentró en las comedias históricas del Fénix que abordan la guerra de Flandes: Los españoles en Flandes, El asalto de Mastrique, Pobreza no es vileza, y en otra comedia, Don Juan de Austria en Flandes, atribuida a Lope pero con grandes dudas.

Esas obras habrían desempeñado una función principal en la construcción/ reflejo de una imagen de la nación, de valor propagandístico, manifiesto en el concepto de porfía, presente en estos textos y que alcanza la plenitud de su sentido como respuesta a la propaganda británica antiespañola.

La elucidación del concepto le lleva primero a la revisión de textos dramáticos de Lope en los que formula su concepción del virtus/vitium de la porfía, positiva o negativamente enjuiciado, las comedias Porfiar hasta morir, Porfiando vence amor y La porfía hasta el temor. Todas tienen por tema al epítome de los amadores del xv y XvI, cuya historia le habría llegado por fuentes poéticas y narrativas, a las que pasa revista y estudia en su significado a menudo construido sobre parejas de elementos contrarios, típicas del cancionero del siglo XV (razón/ voluntad, racionalidad/irracionalidad, etc.) y en las que se funda la novela sentimental. Antes de Lope, otros autores exploraron el empleo de la porfía, como Cervantes, con su historia de Grisóstomo y Marcela, experimentando con su traslado al mundo pastoril y vinculándola, indicativamente, a la figura de esta última y su alegato a favor de la libertad, heredera de la solución de la novela sentimental al problema que surge cuando el código amoroso cortés es inviable como expresión social del amor de los nuevos tiempos. Sólo el matrimonio permite la canalización del sentimiento en la ficción sentimental, porque otorga legitimidad social a los sentimientos; si no existe esa posibilidad, los personajes femeninos despachan a quienes las pretenden haciéndoles saber que sus aspiraciones son palabrería y obsesión.

En segundo lugar, vincula esos textos con un segundo conjunto de comedias de tema relacionado con Flandes o los Tercios, integrado por Los españoles en Flandes, El asalto de Mastrique, Pobreza no es vileza y Don Juan de Austria en Flandes, aunque esta última debe confirmarse que es obra de Lope y no de Alonso Remón. En ellas vuelve a aparecer la porfía para referirse al denuedo del soldado esforzado de los Tercios, aunque también se emplee para denominar la pertinaz rebeldía de los flamencos así como los empecinamientos amorosos de algunos personajes, no siempre enjuiciados negativamente. Por otra parte, Lope lo emplea para explicar la polémica contemporánea de la legitimidad de la guerra de Flandes — que enmascara un conflicto más amplio en el que se dirimía la supremacía mundial económica y mercantil — y la construcción del concepto de España como nación vulnerada por la propaganda hispanófoba europea, con especial atención a la inglesa y en menor medida a la más activa y abundante neerlandesa y francesa. Con el estudio de las obras españolas coetáneas sobre el tema aborda la construcción imaginativa de la nación, el soldado y el conflicto en contraposición a las imáge- 
nes que lanzan la prensa inglesa y europea, lo que lleva al autor a preguntarse si Lope no estaría respondiendo desde el escenario a esa propaganda con unas armas semejantes, aceptando la inutilidad del empleo obras basadas en un razonamiento histórico para responder a los panfletos del enemigo.

En definitiva, Lope explota la manidísima antítesis de amor/guerra, posiblemente con la conocida contraposición de armas y letras al fondo, sin dejar de lado que pudiera existir algún episodio biográfico detrás de las acciones. Macías se incorpora a la historia nacional como figura del español más amante, definida en términos trágicos y de porfía; de manera similar, los soldados están insertos en un contexto de construcción nacional y sometidos a la tiranía del amor. Desde esta perspectiva la esencia española parece identificarse con la porfía en los varios sentidos, una idea en la que se dan cita varios elementos éticos, nacionales, religiosos y amorosos. La hibridación temática es inevitable, porque estos textos se pueden encasillar tanto en la tragedia, por la aparición del ejemplar amante, como entre las obras de tema histórico español o las de tradiciones españolas.

Su sistema de trabajo, siempre basado en el análisis minucioso de los textos, le lleva a abordar la historia del tema de Porfiar hasta morir (32-42), escrita hacia 1624-1628 pero publicada en la Parte XXIII (1638) y representada el 20.06.1636. Posiblemente sea una de las últimas comedias de Lope, por la fecha de representación y publicación. El análisis de su contenido y personajes (42-57) nos presenta a Macías, a través de la narración de su vida de Argote de Molina en Nobleza de Andalucía (1588), posiblemente, aunque añade detalles de localización y personajes y nombres para construir una historia simplemente esbozada por las fuentes. Macías aquí es montañés, y se enamora de Clara, prometida a don Tello de Mendoza. La acción transcurre en Córdoba, con noticias de escaramuzas en la frontera con el reino de Granada y las jienenses Arjonilla o Arjona. Viene Macías con su criado Nuño de la montaña para servir al maestre de Calatrava; en el camino, sin conocerle, le defiende del ataque de unos salteadores. Cuando se presenta para servirle, lo reconoce, no antes, como su salvador y lo toma a su servicio. Trae una carta de Luis Álvarez de Toledo, donde se dice que el joven ha dejado las letras por su inclinación a las armas. La conjunción de ambas lo convierte ya en el perfecto caballero que domina sapientia et fortitudo, o si se prefiere, armas y letras. En la corte conoce a Clara, de la que se enamora con locura, a pesar de las advertencias del criado. Buscando información sobre la dama conoce por un desconocido su compromiso con Tello, un caballero de la corte, asignado por el Comendador, y el amor que le profesa. Cuando Macías pregunta al desconocido su identidad, éste le responde que es el propio Tello. La comedia a esas alturas presenta ya a Macías como un empecinado, porfiado, en cuestiones amorosas, a pesar de las admoniciones de su criado, Nuño, y del propio Tello, además del tema de la honra de Clara. Esa unión conduce, necesariamente, a la tragedia, máxime porque Macías no se da por aludido cuando Clara rechaza sus ofrecimientos; es más, cierra el primer acto con un discurso del enajenado en el que muestra cómo la imposibilidad de la relación espolea sus 
sentimientos y su perseverancia, positiva en abstracto pero contraproducente, que anuncia el desenlace fatal. Las victorias de Macías en la guerra avivan sus intentos de alcanzar la mano de Clara como recompensa del Rey, pero el compromiso previo de la acosada lo impide, sin que cese en su intento y sin que sirvan de nada sirven las advertencias de su criado. El acto II se cierra con la boda de Clara con don Tello, a la que Macías asiste para aumentar su herida, aunque el parlamento final del acto sea de Nuńo, quien abunda en que la locura amorosa de su amo es notoria, lo que pone de manifiesto combinando los remedia amoris ovidianos con conceptos del naturalismo amoroso. La tercera jornada es la resolución del conflicto, con un Macías preso a instancias de $\mathrm{D}$. Tello pero que no cesa en su acoso, poético, a Clara, por lo que el Maestre toma la decisión de ejecutarlo. Como última voluntad, para demostrar ser un amante perfecto, pide a Nuño que comunique al Comendador que perdona a Tello; aquél, admirado de su hombría de bien y sus prendas de leal amador, promete un sepulcro para asentar su memoria en el que figure como cartela: "Aquí yace el mismo amor». La ejecución de Macías no es visible en escena porque la obra no quiere ser una historia de honor mancillado, sino de amor trágico.

Lope explora en la obra las dos facetas de Macías: en cuanto encarnación del amante perfecto, perseverante y sacrificado, la más antigua y lírica, y la del enfermo irracional, destructivo y enloquecido, propia de la narrativa sentimental y otras obras más recientes. A ellas añade una tercera, puramente barroca, la del honor mancillado que debe restituirse. La ausencia de acciones secundarias permite una presentación psicológica minuciosa y profunda, sobria y sin clichés. Macías es un arquetípico amante cortesano, cuya porfía tiene un aspecto positivo, por ser la perseverancia característica innata del amante cortés en cuanto individuo, y tiene una parte negativa por ser socialmente expresión del triunfo del egoísmo sobre el bien común de la paz social. Lope desarrolló el tema de la tragedia amorosa en otras obras como El caballero de Olmedo (1620-1621) y El castigo sin venganza (1631). Son variaciones, distintas soluciones, a historia de amores imposibles, en las que no cabe descartar una cierta identificación autobiográfica. Es de notar que, frente a los otros personajes, Macías es representante, por su condición de montañés, de los españoles genuinos, lo que refuerza con su vinculación religiosa con Santiago de Compostela, tumba del artífice de la reconquista y, por ende, de la unificación de los reinos cristianos; su historia es una apelación a la conciencia colectiva histórica y psicológica de los espectadores.

En otros dos textos, Porfiando vence amor y La porfía hasta el temor, se aborda la operatividad y formas que puede adoptar la perseverancia en la persecución del amor en función de las circunstancias sociales del pretendiente y del pretendido. Porfiando (58) debió ser escrita hacia 1624-1626 ó 1630; narra los amores cruzados de Alejandro y Leonarda y Carlos y Lucinda. Esta última es la porfiada, pues persigue a quien pretende, Carlos, cuando es desterrado por maniobras con las que Alejandro quiere apartarlo de Leonarda. Lucinda, como otras mujeres fuertes, reivindica esa porfía femenina en términos de ingenio y valor. En la obra 
se explora la validez de la firmeza ante los vaivenes de Fortuna, la dimensión positiva de la porfía encarnada en una mujer enérgica que se muestra coherente con sus sentimientos y razones. La porfía hasta el temor sólo ha llegado impresa en la Parte XXVIII de varios autores (Huesca, 1634); si es obra de Lope debió componerse hacia 1595-1604, porque si es posterior, de 1623-1635, no es de Lope. Es una acumulación de varios tipos de textos: comedia de enredo, por los personajes que se esconden y disfrazan; palatina, por los escenarios; de capa y espada, por los lances y bravuconadas, sin olvidar una aparición sobrenatural. El tema tampoco está del todo nítidamente planteado, porque no está claro si la porfía será la de Leonor o la de don Fernando, y durante una sección de la obra parecía que el tema fuera el del poder tiránico, aunque, al final, parece orientarse hacia un contraste entre las desmesuras porfiadas, de signo contrario, de Leonor y don Fernando. La obra podría haber terminado en tragedia, pero su autor prefiere un final tópico de exaltación de la figura femenina, al estilo de Macías. En aquel tiempo ya se había asentado el empleo de la expresión más porfiado que Macías, con el sentido positivo y negativo reunido en ella.

Estas obras exploran el personaje de Macías y, en dos ocasiones, en Porfiando y Porfiar hasta la muerte lo cambia de género para probar las bondades de un esquema de acción que le parece atractivo para su público. La serie se cerraría con El español más amante y desgraciado Macías de Francisco Bances Candamo, última elaboración extensa del tema en el sigLo de Oro. Es un gigantesco enredo de confusiones, disfraces, trazas y engaños, por encima de cualquier otro componente ni reflexión, de cuya acción da cuenta Cortijo Ocaña (87-95).

Tras ese análisis de la porfía amorosa viene el estudio de la bélica, a partir de cuatro piezas que comparten tema y perspectiva, frente a otras que enumera. En las cuatro seleccionadas, Lope vuelve emplear el término porfiar con la misma dualidad de significados que encontrábamos en la trilogía amorosa. Así, en Los españoles en Flandes, Octavio, dirigiéndose a don Juan de Austria califica su empeño, que extiende a la totalidad de la campaña, como una lucha entre la virtus (virtud ética y militar) española y la porfía o perfidia flamenca; la equivalencia entre estos dos términos se desprenden de la definición del término en catalán, valenciano y balear. En la comedia también se emplea la palabra en un contexto amoroso, en la entrevista entre Durán y Marcela, cuando la dama echa en falta que su pretendiente fuera más insistente, al estilo de Macías. Esa misma polisemia ostenta el término en Pobreza no es vileza, El asalto de Mastrique y, aunque se duda que sea obra de Lope ${ }^{2}$, Don Juan de Austria en Flandes; en ellas el significado que predomina es el de "firmeza, valor, virtus militar», vinculado a la imagen

2. Propone Cortijo Ocaña más adelante que (104-105) hay razones para suponerla obra de Lope: la organización de los episodios, la imbricación de las tramas política/bélica y amorosa, el hilo argumental de la lealtad/deslealtad, el relieve dado a la figura del soldado de los tercios, la figura de la mujer flamenca filohispana, episodios de disfraces, etc. 
de España como caracterizada por «por la fe, la fidelidad, la constancia, el valor» (102). sin que esté ausente un ocasional empleo en un contexto sentimental.

En este ciclo, como debe ser denominado por similitudes temáticas y estilísticas, los textos empleados como puntos de partida tenían un propósito propagandístico. La obras se escribieron próximas en el tiempo para una audiencia particular, tal vez a raíz el recrudecimiento de la guerra de Flandes que causó la toma de Ostende (1604). Su sentido nace del panorama histórico en el que están basadas, a partir de textos de Bernardino de Mendoza(Comentario de lo sucedido en las Guerras de los Paises Bajos), Carlos Coloma (Las guerras de los Estados Bajos desde el año 1588 hasta el de 1599), Alonso Vázquez (Los sucesos de Flandes y Francia), Martín del Río, Verdugo y otros. Lope pudo tomar la decisión de escribir estas obras en consonancia con su aspiración a ser Cronista Mayor de Indias o de Castilla.

Los españoles en Flandes trata de sucesos acontecidos en 1577-1578 que culminan con la toma de Gembloux el 30.01.1578; las figuras más importantes son don Juan de Austria y Alejandro Farnesio, enviado por Felipe II a petición de su hermano. Su interpretación oscila entre quienes señalan su carácter probélico y la pintura separada de la realidad de la vida cotidiana de la milicia y quienes la suponen crítica con la política del rey. Incluso algún crítico propone que el conflicto político-religioso es secundario, en vista del problema es la carestía del trigo y el desequilibrio comercial entre Flandes y España.

El asalto de Mastrique, por su parte (107), se basa en los hechos que concluyeron con la toma y saqueo de Maastrich en 1579, que don Marcelino creía reflejado fidedignamente, en vista de las fuentes históricas coetáneas que dan cuenta del acontecimiento; en esa apreciación coincide la crítica posterior, aunque diverjan en qué hechos o aspectos se manifiesta.

Pobreza no es vileza recoge las hazañas en Flandes de Pedro Enríquez de Acevedo, conde de Fuentes, gobernador de los Países Bajos. La acción comienza a la muerte del duque Ernesto, a quien el anterior substituye en el cargo en febrero de 1595 y se extiende hasta la vuelta de las tropas tras la toma de Cambrai el 16.10.1595. Su fuente de inspiración pudo ser una obra de Diego de Villalobos y Benavides (Comentarios de las cosas sucedidas en los paises baxos de Flandes, 1612), especialmente los primeros cincuenta capítulos, que Lope seguiría minucioso, aunque aplica su habitual proceso selectivo de materiales históricos y reconstrucción de los hechos. El tono que se emplea contra los enemigos del reino es menos virulento, como corresponde al periodo de la paz de 1609-1621.

Todas las comedias transcurren en dos muy distintos y marcados planos de la acción: el de los soldados rasos o la contienda, verdaderos protagonistas, y el de los oficiales y jefes, personajes desdibujados que se combinan con narraciones extensas de los hechos militares y nóminas de participantes en el hecho. En ocasiones son excesivamente excéntricos como para poder presentar la acción conjuntada y no resultar tramas excesivamente separadas. El protagonismo de la acción recae en el humilde soldado de Flandes, pintado con variaciones y mati- 
ces, caracterizado siempre por el contraste entre su miseria física y una antitética riqueza moral, que se añade a su lealtad, a pesar de las dificultades, a sus superiores; ello, además, contrasta muy vivamente con la naturaleza felona del rebelde holandés. Los soldados de Lope entran en combate porque persiguen la defensa de la fe católica y restaurar el orden vulnerado por los rebeldes, frente al objetivo de los holandeses, que buscan "hacernos odiosos a todas las naciones del mundo para disculpar su rebelión a entrambas majestades» (Coloma, Guerras de los Estados Bajos). En definitiva, el propósito de Lope en estas obras fue: «Rendir tributo a una profesión y crear, al hacerlo, una imagen idealizada de nación de la que el público se sintiera orgulloso y con la que se identificara» (112), un concepto con el que no todos están de acuerdo. Para ello establece una oposición entre los dos tipos de personajes, siempre caracterizados con las mismas oposiciones: pobreza/ vileza, valentía/cobardía, nobleza/ignominia, amor/desamor.

Pasa Cortijo Ocaña revista a continuación al contexto español y europeo en el que surgen las obras de Lope. No contamos, desafortunadamente, con la profusión de epígrafes del capítulo I, que ayudaron al lector con su ordenación del sentido del texto. Se diría que el propio autor tiene conciencia de la condición de digresión de una larga, y brillantísima, sección en la que aborda el contexto europeo (La construcción de Espańa en la prensa europea, 128-177), a tenor del epígrafe con que denomina la sección siguiente (De vuelta al ciclo de Flandes de Lope de Vega, 177-194).

Entender por qué Lope emplea materiales e ideas de Mendoza y Coloma exige abordar cuáles fueron las razones para que el dramaturgo los escogiera de entre todos los que tenía a su alcance. Ambos historiadores tenían mucho en común: su relación con los tercios, su condición de embajadores en Inglaterra, con responsabilidades administrativas entre 1580-1630, combatientes sobre el terreno en Flandes y defensores con su actividad política de la monarquía hispana y la religión católica. Conocen de primera mano la situación política europea contemporánea, las principales reflexiones politológicas y las campañas propagandísticas antiespañolas de mayor o menor calado que lanzan los rivales de la monarquía hispana. Su reacción nace de su convicción del partidismo de los escritos antiespañoles, que emplean como motivo de sustentación de sus mitos nacionales en la narrativa histórica de sucesos bélicos recientes.

La disputa que comenzó en el campo teológico pasó de dirimirse con argumentos a sustentarse con armas. Al principio, el bando imperial tenía la ventaja de contar con un ejército frente a sus dos rivales, Flandes y Gran Bretaña, que tuvieron que construir sus ejércitos mediante recluta en una población sensiblemente inferior a la potencia militar que le daban todos los integrantes del imperio a los españoles (flamencos, borgoñones, italianos y alemanes); además, aquellas naciones padecían la dificultad de estar integradas por una población de ideas muy distintas, cuando no enfrentadas, por lo que resultaba fácil que una potencia extranjera aprovechara esas desavenencias para usar algún grupo como quinta columna. 
Flandes fue el primer país en independizarse aunque en términos legales y de teoría política de la época sea un proceso de difícil justificación, dado que entonces la sublevación es un delito contra el derecho establecido que comporta la categoría de crimen de lesa majestad; además no fue una iniciativa unitaria, pues las provincias del norte y del sur no tenían precisamente el mismo punto de vista, una homogeneidad que distaba de existir dentro de cada zona, incluso lingüísticamente hablando. Ante esa situación, la Holanda rebelde tuvo que realizar una campańa de propaganda con dos objetivos: justificar ante los ojos de Europa su levantamiento contra el orden legal, y que en clave interna le sirviera para atraer voluntades y galvanizar a los ya comprometidos. En el caso inglés esa necesidad llega a extremos difíciles de entender; el protestantismo inglés, impuesto por la monarquía, se convierte con Isabel I en causa patriótica. Por razón de estado, la reina y su gobierno han de reprimir y controlar la abundante población inglesa católica, potenciales colaboradores de un agresor externo remoto, el imperio español, o próximo, Irlanda. Ese posible enemigo interno, a quien Coloma y Mendoza aspiran a emplear muy tempranamente, entre 1560-1580, según ha puesto de manifiesto Cortijo Ocaña, provocó el apoyo inglés a Holanda con la intención estratégica de abrirle un segundo frente al reino de España y lanzarse a demonizar al enemigo en una campaña de intoxicación y propaganda sin precedentes que termina por producir la leyenda negra. Las más de las publicaciones europeas que trataron de Espańa y lo español estaban escritas en holandés, inglés, francés, y en menor medida en italiano y sólo algunas en latín.

La respuesta de la corona española en el campo de la propaganda pasó por la producción de razonadas publicaciones históricas; su falta de efectividad, como expone el autor, nace de tratarse de obras de historia, que pasó a ser una disciplina a medio camino entre filosofía y poesía, aunque con la recuperación de Tácito como autor ejemplar adquiere un ímpetu moral que no tenía en la edad media. Eso le proporcionó un estatuto nuevo de reflexión filosófico-moralizante, y por tanto con una dimensión práctica, que no implica el abandono de su concepción de verdad objetiva; por eso no resulta eficaz contra el panfleto propagandístico interesado en transmitir un mensaje ideologizado y reduccionista en su contenido.

En su desarrollo tuvieron especial importancia las concepciones de la historia y el historiador próximas a la política y el político del humanista español Sebastián Fox Morcillo hacia la primera mitad del siglo Xvi. Para él, el historiador debe tener, por su conocimiento de la realidad coetánea, labores de consejero político, independiente de las ideas de quien lo emplea; no puede quedarse al margen de la realidad, entregado a sus estudios, sino participar en el devenir de la comunidad política y de la nación como consejero, porque el fin último de toda la República no es simplemente obtener la tranquilidad, beneficio, paz y abundancia, sino alcanzar la justicia y honestidad en la vida y acciones.

Las obras de Mendoza y Coloma, que son producto de sus experiencias vitales, persiguen la construcción de una historia que responda a la verdad y además sea útil en el combate de las ideas. Si en el campo de batalla la lucha 
está presidida por la defensa de la legitimidad de la causa apoyada, la virtus, militar y moral, y la fuerza/ingenio con las armas, en el espacio del texto sigue un esquema paralelo, ya que se persigue la objetividad (legitimidad), la virtus de la reflexión moral y la fuerza de la verdad. Esa legitimidad de la causa nacería para Bernardino de Mendoza del providencialismo; de ahí su constante apelación a la necesidad de que la nación adopte un comportamiento acorde con esa creencia. Cortijo Ocaña supone que también puede tratarse de una reacción al providencialismo de los protestante, en especial de Calvino, que fue utilizado para apoyar la campaña de propaganda inglesa tras el desastre de la Gran Armada. De origen religioso sería igualmente la identificación del enemigo con el diablo, por su rebelión contra un monarca que es el defensor Fidei, y la calificación de su pecado de egoísmo, falta de obediencia y de caridad. No en vano, el rey tiene que ser también actor de la difusión de la semilla evangélica.

Pero Lope lleva a las tablas asuntos que trascienden lo bélico como espectáculo y entran dentro de la categoría de la construcción de una conciencia histórica colectiva. Forman parte de un grupo de obras más amplio, denominado histórico, en el que los textos tienen un valor ejemplarizante, como señaló en el prólogo a La campana de Aragón, porque la representación transmite la profundidad de la vida humana y la diversidad de los sucesos que caben en ella. Lo que mueve a Lope, por tanto, es un punto de vista semejante al de Bernardino de Mendoza, Carlos Coloma y otros autores españoles, que intentan rebatir la propaganda antiespañola en forma de contestación o diálogo con esas obras polemistas europeas, aunque en clave de consumo interno y en expresión teatral. Los propios historiadores holandeses, ingleses y franceses reconocen que la propaganda española fue mucho menor en su volumen y virulencia, y producto de la reacción ante la agresión previa de Holanda seguida de Inglaterra.

El autor se enfrenta al espinoso tema de los verdaderos orígenes de la imagen negativa del reino de España que surge en esta época en unas páginas tan personales como brillantes (136-passim). Entre 1580 y 1590 se produce el momento culminante de la lucha religiosa entre protestantes y católicos en Europa occidental y central, pero ya desde 1558 se había constituido la división en los bandos que después se enfrentan. La concordia era una realidad en la región germanoparlante; Italia y España eran claros partidarios de la causa católica, frente a triunfante reforma protestante en las Provincias del Norte de los Países Bajos y en amplias zonas de Hungría y Bohemia. En los territorios de la región que hoy se extiende entre Polonia y Lituania convivían ambos cultos, a diferencia de lo que sucedía en Francia e Inglaterra, en los que la batalla está en plena efervescencia. Detrás de estos enfrentamientos se encuentran la razón de Estado y grupos políticos en proceso de construcción, cuyo manejo del poder y construcción de la ideología son los verdaderos orígenes, nada espirituales, de los conflictos religiosos que asolan Europa; al proceso lo denomina muy gráficamente «nacionalización de la religión", que implica que los súbditos sean objeto de un adoctrinamiento religioso, empleando imágenes y retórica bíblica, con toda la intensidad 
que permiten en aquel momento la imprenta y la supeditación de la región a los intereses nacionales (138). No obstante, el autor reconoce la existencia de un acendramiento de la conciencia religiosa al lado de una intransigencia extrema en ambos bandos, que acallan las llamadas a la paz que también desde ambas posiciones aparecen periódicamente. Los excesos cometidos contra la población por estas razones son parejos en ambos bandos.

$\mathrm{Al}$ igual que nadie está libre de culpa por esos excesos, tampoco las aspiraciones a implantar una ortodoxia centralista y centralizadora son ajenas a ninguno de los contendientes, como ponen de relieve las directrices papales, las filipinas, las que salen de la Ginebra de Calvino o en las de la Inglaterra isabelina. Los tópicos juicios que convierten en fanática la política de nuestro Felipe II, legítima la de Guillermo de Orange o astuta la de Isabel I no tiene ningún valor histórico, como tampoco lo tiene la explicación muy extendida del deseo de la reina inglesa de salvaguardar la soberanía de su país, porque lo mismo se podría decir de las intenciones de Felipe II con los Países Bajos, que conviene recordar habían sido recibidos como parte de su herencia.

La finalidad de aquellos escritos hispanófobos era despertar el miedo de las naciones europeas a una agresiva, codiciosa y violenta potencia española, obsesionada con asesinar y expoliar a todos los no católicos, tópicos ya empleados a raíz de la literatura panfletaria aparecida tras el saco de Roma en 1527. Caracterizan a Espańa su arrogancia y su sed de sangre y oro, que ya se había puesto de manifiesto en la masacre de la población indígena americana, como ya habría documentado Bartolomé de las Casas, cuya obra traducida se difunde extraordinariamente por Holanda e Inglaterra. Esas ideas las verbalizan varios personajes flamencos en las comedias de esta trilogía de Lope, para quienes el español es un hipócrita obseso, egoísta y cobarde, un asesino despiadado con sed de sangre a quien hay que destruir.

Semejantes campańas de adoctrinamiento y propaganda, con otros destinatarios, se producían igualmente en España, e incluso muy tempranamente, como apunta el Razonamiento de Antonio de Villalpando en la época de los Reyes Católicos. Ni que decirse tiene que también los distintos enemigos de la corona española, comenzando por los franceses, emplearon similares métodos desde los primeros tiempos de la imprenta. El resumen de la documentación de Salavert Fabiani aporta un panorama de los variados motivos que se emplearon contra los monarcas españoles, sus alianzas y su política europea y las causas de la operación propagandística. Nada que no hubiera hecho el bando español en otras circunstancias, porque las batallas que hubo entre la Gran Armada y la escuadra inglesa se dirimieron no sólo en el mar sino también en la imprenta, como recoge minuciosamente Cortijo Ocaña.

Una vez construido ese panorama, el autor vuelve al ciclo de Flandes para señalar que el dramaturgo no sólo intenta crear una imagen de la nación sino también responder a esas campañas propagandísticas antiespañolas. Con las piezas de este ciclo incide reiteradas veces en la defensa de la legitimidad de aquella guerra, puesto que los súbditos la han iniciado al sublevarse contra su legítimo 
rey y además está desangrando la economía española sin que se produzca beneficio alguno, lo cual prueba que los soldados no reciban sus pagas y mueran por miles. El argumentario español se manifiesta también en la presentación de la guerra como un mal inevitable y contrario al propósito del monarca espańol, que persigue la paz y la prosperidad para todos que impide la rebelión flamenca. En su piezas refleja imágenes de lo flamenco tomadas de cinco crónicas espańolas de la guerra anteriores a 1609, las de Alonso de Ulloa, Pedro Cornejo, Bernardino de Mendoza, Antonio Trillo y Martín Antonio del Río. Así los flamencos aparecen como unos herejes, rebeldes, crédulos, simples y obcecados, arrogantes y desagradecidos, desleales (en especial los aristócratas) y pertinaces, con un resentimiento y odios profundos hacia España. Sin embargo la imagen espańola es la de un pueblo elegido por Dios, valientes y esforzados, creyentes y que únicamente tienen como vicio el de su arrogancia.

Para contrarrestar todo esto Lope pone en primer plano los vínculos afectivos existentes entre Flandes y España en tanto en cuanto son territorios ab initio de la corona de los Austrias españoles y, además, porque los soldados españoles han fundado familias con flamencas, que a menudo aparecen disfrazadas de hombres y se enfrentan a sus connacionales o a sus propios parientes en la búsqueda de sus amantes, y son manifestación de la creencia en la bondad de España con Flandes. También se enfrenta con sus piezas a la acusación de la codicia, con acciones protagonizadas por soldados hambrientos, desinteresados y valientes, en estado de necesidad permanente, que luchan espoleados por el sentido del deber, que les permite olvidar las numerosas bajas en combate y rechazar siempre cualquier intento de comprar sus voluntades con dinero. La miseria y la pena se alivian con momentos divertidos protagonizados por el gracioso, como la disputa sobre la supremacía del vino o la cerveza del primer acto de Los españoles en Flandes. Lope construye una milicia idealizada donde la carencia de bienes materiales se compensa con altas dosis de virtus moral y militar. No obstante, los soldados españoles están a medio camino entre la ejemplaridad y la fanfarronería de los milites gloriosi, encarnación del orgullo español, con notas de pícaros achulados. A cambio, este personaje colectivo representa, en último término, en el sacrificio del pueblo español en aras de la causa nacional. Ni que decirse tiene que esta pintura amable y desligada de los horrores de la guerra, aunque se incluyan algunas notas de pintoresquismo bélico, permitiría la identificación del espectador con el soldado español, que vería con simpatía sus necesidades y sus alardes de ingenio para superar las dificultades, al margen de apreciar su valor, su lealtad y su porfía.

Un tema muy frecuente es el de la caracterización de la rebelión de los Países Bajos como un delito con ribetes de ofensa personal, una formulación que se repite en los tratados políticos y propagandísticos hispánicos del tiempo. Como era de esperar, la trama política se ve reflejada en la amorosa secundaria para hacer visibles virtudes y vicios como fidelidad e infidelidad, confianza y desconfianza. Por eso se repite una estructura habitualmente en los episodios bélicos, reflejados en la subtrama amorosa: asalto español, resistencia holandesa, victoria española, 
laudatio de los ganadores. Abundan en ellas el enredo muy desarrollado y la ocultación de la identidad mediante el disfraz de los personajes femeninos.

El libro termina volviendo de nuevo sobre la porfía, su concepto y presencia en Lope (207-224), en una posición un tanto colateral respecto a la construcción del razonamiento, aunque posiblemente sea un corolario necesario.

Persigue el empleo de la porfía en el resto de la producción teatral del Fénix: casi en un millar de ocasiones en 264 obras. El análisis al que somete los términos discurre por caminos ya recorridos: su doble valoración y sentido en el campo de los sentimientos y del enfrentamiento bélico, su empleo para caracterizar a los soldados españoles en escena, que encarnan con sus pasiones y sus hechos heroicos una imagen de lo español que se opone muy fácilmente a la perfidia de los traidores flamencos y su infidelidad amorosa y política. El término porfía encarna la narrativización del amor de acuerdo con los moldes del siglo xv, que lo conciben como una contienda que enfrenta lógica e irracionalidad en un proceso discursivo y dialéctico. De esa colisión nace este concepto dialéctico del amor como fuerza en tensión y movimiento. Es posible que tras esa preferencia de Lope hubiera algún tipo de justificación biográfica. En su vida hubo tiempo y espacio para el amor entendido de esta forma e incluso para la participación en empresas militares y políticas.

Cuestión aparte y de difícil solución es dilucidar la postura de Lope ante la guerra; hay opiniones contrapuestas, pero el autor argumenta que no puede conocerse su opinión sobre el tema a partir de los personajes que hace subir al escenario. Esas figuras, tanto los soldados de los tercios como los rebeldes flamencos, se construyen sobre las imágenes que transmiten las crónicas de Flandes espańolas; además, los enemigos aparecen adornados de vicios que caracterizaban otros enemigos del imperio, como indígenas americanos, guanches de Tenerife, italianos e ingleses. Por otra parte, también hubo de emplear materiales de textos propagandísticos extranjeros, por cuanto en sus textos afirma explícitamente en ocasiones que quiere responder a las falacias y la tergiversación que se hace de la historia de España. La insistencia en la deslealtad y el desprecio hacia los españoles que los personajes flamencos muestran es trasunto de la valoración política de la rebelión que hacen los historiadores españoles. Ese concepto de la legalidad se presenta bajo varias formas en las obras de Lope, ya sea a través de la idea de la guerra justa (defensiva), ya sea a través de la censura de la traición flamenca en cuanto delito de lesa majestad por rebelarse contra su soberano legítimo. La deslealtad de los rebeldes se expresa en términos equivalentes a los de la vulneración del honor de las comedias, aunque en este caso ha sido España quien ha sido mancillada y por cuyo honor deben volver los soldados.

Esta actitud hay que verla encuadrada en la construcción de una historia nacional sobre las tablas centrada generalmente en figuras del Romancero y en especial en la figura de los Reyes Católicos. En ese afán de celebración del espańol, Lope recalca orgulloso algunas virtudes y características españolas pero no deja de lado otras notas menos favorables de soldados, jefes y políticos (arrogan- 
cia, insumisión, afán de lucro, etc.), tal vez meramente por resultar verosímil en su imitación de la realidad. No obstante, es indudable que Lope está convencido de la ilegalidad de la guerra declarada por los flamencos y, por tanto, de que la participación defensiva española en la misma es legal y ajustada a derecho, concepto con el que se enfrenta a uno de los principales puntos de la propaganda de la leyenda negra coetánea.

El autor propone que la presencia de afirmaciones semejantes en La Circe, donde critica duramente a los historiadores extranjeros por el trato que dan a España, unido al contexto histórico político en el que la defensa de la verdad se constituye en eje de la defensa de España, junto con su interés por un puesto de cronista real, amén de la escritura de otras obras sobre el tema de La Dragontea, podrían inclinarnos a aceptar que Lope estaba convencido de la legalidad de la guerra espańola en Flandes y los principios en que se sustenta tal idea. Y ello no por acatamiento de una imposición del aparato del poder real, sino, como analiza el autor con García Hernán respecto al sistema ideológico en su conjunto, por ser «el resultado de la negociación y el diálogo con los súbditos» (2006: 202).

Las fuentes de información que maneja son tan ricas que resultaría ridículo pretender señalar usencias de conceptos o textos; los estudios que propongo, de consulta imposible los más para su autor por una cuestión de cronología, son producto del estímulo que me supuso lo que aprendí con este libro. Si algún lector de esta revisión quisiera perfilar, que no ampliar su información, sobre algunos de estos conceptos podría recurrir a los estudios de Manzano Baena (2001 y 2002) para una caracterización de España en la crítica de holandeses y alemanes. En el caso de la representación de esos conflictos en la escena espańola hay noticias de interés en las actas sobre el tema que compilaron Barsacq \& García García (eds.) (2005) y Pedraza Jiménez, González Cañal \& Marcello (eds.) (2012), y si miramos hacia el teatro inglés es interesante Griffin (2009). Para profundizar en la interesante cuestión de la propaganda inglesa antiespańola es el propio Cortijo Ocaña (2014) quien ha editado sendas composiciones inglesas que tienen tal tema. Finalmente, un estado de la cuestión con interesantes confirmaciones de algunos puntos expuestos en este libros se encuentra en Rodríguez Pérez, Sánchez Jiménez $\&$ den Boer (eds.) (2015). El exceso de información convierte en misión casi imposible la vertebración estructurada de esta monografía, en la que hubiera sido muy de agradecer una distribución tal vez más escolar, que habría permitido aprehender un panorama tan rico de noticias y perspectivas. El empleo de un tipo de letra y un interlineado reducidos, aunque no afecten a la legibilidad del texto, así como la ampliación de la caja de la página al máximo posible, sin caer en excentricidades, explican cómo un libro de 254 páginas pueda contener semejante caudal de información. La peor dificultad para la consulta del libro no es atribuible al autor: el sistema de cita bibliográfica, sin año, no permite identificar los ítems bibliográficos cuando los autores tienen más de una entrada o sus apellidos coinciden; por ejemplo, en la 
nota 14 de la pág. 112 se menciona a un Smith, apellido que en la bibliografía (248) tiene tres entradas de dos autores diferentes, o Coates, que en la bibliografía final (233) tiene dos entradas.

En una obra con semejante abundancia de bibliografía es normal que se escape algún autor citado en nota pero sin identificar en la bibliografía final, como sucede en la página 112, n. 14, donde aparece un Martín relacionado con la guerra santa; en la página 115 cita a Pineda como estudiosa de Fox pero no recoge en la bibliografía final que se trata de Pineda, Victoria. La imitación como arte literario en el siglo XVI español. Sevilla: Diputación, 1994. Algo semejante sucede con un Kevin (163-164) que aparece en la página 142 o un Vermaseren en la página 181 que no se recogen en la Bibliografía. Son daños colaterales de una monografía densa y rica, como en el caso de la extensa cita en páginas 135136 en la que indica el autor, pero no los datos bibliográficos de su procedencia.

Cada libro impone una forma distinta de lectura, y el texto de Cortijo Ocańa reclama de sus lectores atención y consulta con un soporte para tomar nota de atinadas interpretaciones, excelentes análisis y una riqueza documental nada habitual en el abordaje de estos temas. 


\section{Bibliografía}

Álvarez Amo, Francisco J., «Significado y función de los catálogos de poetas españoles del siglo XVI», en Begoña López Bueno (ed). El canon poético en el siglo XVI: VIII Encuentro Internacional sobre Poesía del Siglo de Oro, (Universidad de Sevilla, 21-23 de noviembre de 2006). Sevilla: Universidad, 2008, págs. 215-234.

BarsacQ, Alain y Bernardo José García García (eds.), Hazañas bélicas y leyenda negra: argumentos escénicos entre España y los Países Bajos : Coloquio Internacional, Béthune, 25-26 de marzo de 2004. Madrid: Fundación Carlos de Amberes, 2005.

Bloemendal, Jan (ed.), Neo-Latin drama forms, functions, receptions; [thirteenth congress of the International Association of Neo-Latin Studies at Budapest, 6-13 August 2006]. Hildesheim: Olms, 2008.

Carreño, Antonio, "Alejandro García Reidy, Las musas rameras. Oficio dramático y conciencia profesional en Lope de Vega», Anuario Lope de Vega: Texto, literatura, cultura, 21 (2015), págs. 197-208. Accesible en línea: <http:// dialnet.unirioja.es/descarga/articulo/4961226.pdf>.

—, «El Laurel de Apolo de Lope de Vega y otros laureles», Bulletin hispanique, 106 (2004), págs. 103-128. Accesible en línea: <http://www.persee.fr/doc/ hispa_0007-4640_2004_num_106_1_5183>.

—, "Lope y el ciclo de iuventute», Iberoromania: Revista dedicada a las lenguas y literaturas iberorrománicas de Europa y América, 56 (2002), págs. 4-32.

Clemente San Román, Yolanda, Tipobibliografía madrileña. La imprenta en Madrid en el siglo XVI (1566-1600) [Tenemos un ejemplar en la biblioteca general, pero quiero uno en la nuestra]. Kassel: Reichenberger, 1998. 3 vols.

Coloma, Carlos, Las Guerras de los Estados Bajos (desde el año de 1588 hasta el de 1599). Edición de Antonio Cortijo Ocaña. Madrid: Ministerio de Defensa, 2010.

Cortijo Ocaña, Antonio, "Lope porfiado», Cincinati Romance Review, 38 (2014), págs. 147-177. Accesible en línea: <www.cromrev.com/volumes/ vol38/CRR\%20v38-A10\%20Cortijo.pdf>.

Couderc, Christophe, Le théâtre espagnol du Siècle d'Or: (1580-1680). Paris: PUF, 2007.

- (ed.), Le théatre espagnol du siècle d'or en France (XVIIe-XXe siècle) de la traduction au transfert culturel. Nanterre: Presses universitaires de Paris Ouest, 2012.

Cueva, Juan de la, Primera parte de las comedias y tragedias de Ioan de la Cveva. Dirigidas a Momo [Van añadidos en este segunda impression, en las Comedias y Tragedias Argumentos, y en todas las Iornadas. Enmendados mvchos yerros y faltas de la primera impressión]. Sevilla: Joan de León, a costa de Fernando de Medina Campo, 1588. Accesible en línea: <http://www.cervantesvirtual. com/servlet/SirveObras/03695177566895195632268/index.htm>. 
D’Antuono, Nancy L., «La comedia española en la Italia del siglo Xvir: La commedia dell'arte», en Henry W. Sullivan, Raúl A. Galoppe \& Mahlon L. Stoutz (eds). La comedia española y el teatro europeo del siglo XVII. Woodbridge: Tamesis, 1999, págs. 1-36.

Damas en el tablado. XXXI jornadas de teatro clásico, Almagro, 1, 2 y 3 de julio de 2008. Edición de Almudena García González, Felipe B. Pedraza Jiménez \& Rafael González Cañal. Cuenca: Universidad de Castilla-La Mancha, 2009.

Diccionario Filológico de Literatura Española siglos XVI-XVII. Volumen I (Siglo XVI). Volumen II (Siglo XVII, letras A-M). Volumen III (Siglo XVII, letras N-Z). Edición de Pablo Jauralde Pou (dir.), Delia Gavela \& Pedro C. Rojo Alique (coords.). Madrid: Castalia, 2009-2010. 3 vols.

Díez Borque, José María. Literatura (novela, poesía, teatro) en las bibliotecas particulares del Siglo de Oro español (1600-1650). Pamplona-Madrid-Frankfurt am Main: Universidad de Navarra, 2010.

Díez Borque, José María y Álvaro Bustos Tùler. Literatura, bibliotecas y derechos de autor en el Siglo de Oro, 1600-1700. Madrid: Iberoamericana, 2012.

Enciso Alonso-Muñumer, Isabel, «Nobleza y mecenazgo en la época de Cervantes», Anales cervantinos, 40 (2008), págs. 47-61. Accesible en línea: $<$ http://analescervantinos.revistas.csic.es/index.php/analescervantinos/article/ view/36/36>.

—, "Poder y cultura: literatura y nobleza a comienzos del xviı», en José N. Alcalá-Zamora \& Ernest Belenguer Cebrià (eds). Calderón de la Barca y la España del Barroco 2. Madridid: entro de Estudios Políticos y Constitucionales, 2001, 2 vols. T. 2 págs. 447-475.

Ferrer Valls, Teresa, «Lope y la tramoya de la corte: entre tradición e innovación», Anuario calderoniano, (1) (2013), págs. 163-189.. Accesible en línea: <http://www.cervantesvirtual.com/obra/lope-y-la-tramoya-de-lacorte-entre-tradicion-e-innovacion/>.

—, Diccionario biográfico de actores del teatro clásico español (DICAT), edición digital. Kassel: Reichenberger, 2008.

—, «La incorporación de la mujer a la empresa teatral: actrices, autoras y compañías en el Siglo de Oro", en F. Domínguez Matito \& J. Bravo Vega (eds). Calderón entre veras y burlas. Actas de las II y III Jornadas de Teatro Clásico de la Universidad de La Rioja (7, 8 y 9 de abril de 1999 y 17, 18 y 19 de mayo de 2000). Logroño: Universidad de la Rioja, 2002, págs. 139-160. Accesible en línea: <http://www.uv.es/entresiglos/teresa/pdfs/la\%20rioja.pdf>.

Ford, Philip y TAYLOR, Andrew (eds.), The early modern cultures of Neo-Latin drama. Leuven: Leuven University Press, 2013.

Gallego Morell, Antonio, La imprenta en Granada. Edición de José Antonio Cordón García, Cristina Peregrín Pardo \& Cristina Viñes Millet. Granada: Universidad, 1997.

García Aguilar, Ignacio, "Varones nobles y nobles poetas: los repertorios de ingenios en el Siglo de Oro», en M. Begońa López Bueno (ed). En torno al 
canon, aproximaciones y estrategias: VII Encuentro Internacional sobre Poesía del Siglo de Oro. Sevilla: Universidad, 2005, págs. 285-316.

García Hernán, David, La cultura de la guerra y el teatro del Siglo de Oro. Madrid: Silex, 2006.

Griffin, Eric J. English Renaissance Drama and the Specter of Spain Ethnopoetics and Empire. Philadelphia, Pa.: University of Pennsylvania Press, 2009.

García-Bermejo Giner, Miguel, «"estando letras y armas en su punto”: Teatro y poder en la España de hacia 1580», en Folke Gernert, Javier Gómez Montero \& Florence Serrano (eds). Del pensamiento al texto. Textualización del saber en el Renacimiento español. Vigo: Academia Editorial del Hispanismo, 2013, págs. 85-122.

—, "me pedís que escriba arte de hacer comedias": Estrategia y contenido del Arte nuevo de Lope», Romanistisches Jahrbuch, 60 (2009), págs. 318-339.

Garzoni, Tomaso, La Piazza Vniversale Di Tvtte Le Professioni Del Mondo, E Nobilie Et Ignobili. Venetia: Somascho, 1585. Accesible en línea: <http:// diglib.hab.de/drucke/sch-p-87/start.htm>.

Gómez Gómez, Jesús, El modelo teatral del último Lope de Vega (1621-1635). Olmedo (Valladolid): Ayuntamiento de Olmedo-Universidad de Valladolid, Secretariado de Publicaciones e Intercambio Editorial, 2013. <http://ia310809.us.archive.org/2/items/bibliografiamadr03pruoft/ bibliografiamadr03pruoft.pdf>.

<http://ia600504.us.archive.org/22/items/bibliografamadr02pastgoog/ bibliografamadr02pastgoog.pdf>.

IzQuierdo Domingo, Amparo, "Los autos sacramentales de Lope de Vega: estado de la cuestión y propuesta de estudio", Teatro de palabras. Revista sobre teatro áureo, 7 (2013), págs. 497-515. Accesible en línea: <http:// www.uqtr.ca/teatro/teapal/TeaPalNum07Rep/28IzquierdoAmparo.pdf>.

-, "Secretarios reales y eclesiásticos en los autos sacramentales de Lope de Vega», en Mariela Insúa Cereceda \& Felix K.E. Schmelzer (eds). Teatro y poder en el Siglo de Oro: BIADIG : Biblioteca áurea digital v.18. Pamplona: Universidad de Navarra, 2013, págs. 109-122. Accesible en línea: <http:// hdl.handle.net/10171/34310>.

-, Los autos sacramentales de Lope de Vega. Clasificación e interpretación. Vigo: Editorial Academia del Hispanismo, 2013.

Kaufmant, Marie-Eugénie, «Alejandro García Reidy, Las musas rameras. Oficio dramático y conciencia profesional en Lope de Vega», Mélanges de la Casa de Velázquez, 45.1 (2015), págs. Descargado. Accesible en línea: <http://mcv. revues.org/6409>.

Lasso de la Vega, Gabriel Lobo, Primera parte del romancero y tragedias de Gabriel Laso de la Vega. Alcalá de Henares: en casa de Juan Gracián, que sea en gloria a costa de Juan de Montoya mercader de libros, 1587.

Latorre Ciria, José Manuel y Serrano Martín, Eliseo (eds.), Discurso religioso y contrarreforma. Zaragoza: Institución Fernando el Católico, 2009. 
Lefevere, André, Traducción, reescritura y la manipulación del canon literario. Salamanca: Colegio de España, 1997.

Maestro, Jesús G., «Aristóteles, Cervantes y Lope: El Arte nuevo: de la poética especulativa a la poética experimental», Anuario Lope de Vega, 4 (1998), págs. 193-208. Accesible en línea: <http://www.cervantesvirtual.com/ servlet/SirveObras/01350508600026383533680/index.htm>.

MaIner, José-Carlos, Historia, literatura, sociedad (y una coda española). Madrid: Biblioteca Nueva, 2000.

Manzano Baena, Laura, «Inventando al enemigo: imágenes de "España” en las Provincias Unidas», en Manuel Herrero Sánchez \& Ana Crespo Solana (eds). España y las 17 provincias de los Paises Bajos: una revisión historiográfica (XVI-XVIII). Córdoba: Universidad, 2002. 2 vols. T. 2 págs. 775-796.

—, «La imagen de la Monarquía Hispana en la propaganda europea (s. XVIXVII)", Espacio, tiempo y forma. Serie IV, Historia moderna, 14 (2001), págs. 197-244. Accesible en línea: <http://dialnet.unirioja.es/servlet/ extart?codigo $=1036894>$.

Martínez Berbel, Juan A. y Castilla Perez, Roberto (eds.). Las mujeres en la sociedad española del Siglo de Oro, ficción teatral y realidad histórica. Actas del II Coloquio del Aula-Biblioteca "Mira de Amescua", celebrado en GranadaÚbeda, 7 al 9 de marzo de 1997 y cuatro estudios clásicos sobre el tema. Granada: Universidad, 1998.

McCormick, Colleen Marie, "The rhyming monsieur and the Spanish plot»: transnational dimensions of early modern theater in western Europe. Dirigida por Green, Harvey. Boston: Northeastern University, 2014. Accesible en línea: <http://hdl.handle.net/2047/d20005080>

Mendoza, Bernardino de, Comentarios de don Bernardino de Mendoça de lo sucedido en las guerras de los Países Baxos, desde el año de 1567 hasta el de 1577. Edición de Antonio Cortijo Ocaña \& Ángel Gómez Moreno. [Madrid]: Ministerio de Defensa, Secretaría General Técnica, 2008.

Norland, Howard B. y Jan Bloemendal (eds.), Neo-Latin drama and theatre in early modern Europe. Leiden: Brill, 2013. Préstamo trier

Paun de García, Susan (ed.). The Comedia in English translation and performance. Woodbridge: Tamesis, 2008.

Pedraza Jiménez, Felipe B. Lope de Vega: Vida y literatura. Valladolid: Universidad, 2008.

—, El universo poético de Lope de Vega. Madrid: Ediciones del Laberinto, 2002.

Pedraza Jiménez, Felipe B., González Cañal, Rafael y Marcello Elena E. (eds.). Europa (historia y mito) en la comedia española. Cuenca: Servicio de Publicaciones de la Universidad de Castilla-La Mancha, 2012.

Pérez Pastor, Cristóbal, La Imprenta en Medina del Campo (Reprod. facs. de la ed. de Madrid: Establecimiento Tipográfico Sucesores de Ribadeneyra, 1895). Edición y estudio introductorio de Pedro M. Cátedra. Valladolid: Junta de Castilla y León. Consejería de Cultura y Turismo, 1992. 
-, Bibliografía madrileña o descripción de las obras impresas en Madrid. (siglo XVI). Vol. I, siglo XVI - Vol. II, 1601-1620 - Vol. III, 1621-1625. Madrid: Tipografía de los huérfanos, 1891. 3 vols.. Accesible en línea: <http://ia600402.us.archive.org/0/items/bibliografamadr00spagoog/ bibliografamadr00spagoog.pdf>

Profeti, Maria Grazia, Commedie, riscritture, libretti la Spagna e l'Europa. Firenze: Alinea, 2009.

Rodríguez Cuadros, Evangelina, "Autoras y farsantas: la mujer tras la cortina», en Mercedes de los Reyes Peña (ed). La presencia de la mujer en el teatro barroco español [seminario celebrado en] Almagro, 23 y 24 de julio de 1997]. Sevilla: Junta de Andalucía, 1998, págs. 35-65.

Rodríguez Pérez, Yolanda, Antonio Sánchez Jiménez \& Harm den Boer (eds.). España ante sus críticos: las claves de la Leyenda Negra. Madrid [u.a.]: Iberoamericana [u.a.], 2015. pedido

Romera Navarro, Miguel, «Las disfrazadas de varón en la comedia», Hispanic Review, 2.4 (1934), págs. 269-286. DOI: 10.2307/470282.

Ruiz PÉrez, Pedro, «En los inicios del canon lírico áureo», Voz y letra: Revista de literatura, 15.1 (2004), págs. 25-52. Accesible en línea: <http://search. ebscohost.com/login.aspx?direct $=$ true \&db=a9h\&AN=16195057\&site =eh ost-live>.

SÁnchez Hernández, Sara, "Reseña "De musas rameras o el oficio dramático y conciencia profesional de Lope de Vega, por Alejandro García Reidy” ", Leer Teatro, 5 (2014), págs. Descargado. Accesible en línea: <http://www.aat.es/ elkioscoteatral/leer-teatro/leer-teatro-5-sumario/n-o-5-mejor-pensarlo-dosveces-6-3-ensayo/>.

SÁNCHEZ, Juan M. Bibliografía aragonesa del siglo XVI (1501-1600). Edición de María Remedios Moralejo Álvarez \& L Romero Tobar. Madrid: Arcos Libros, D.L, 1991. 2 vols.

SAnz Ayán, Carmen. «De la «Pax Hispánica a la guerra contra todos. Apuntes sobre la evolución de paradigmas historiográficos relativos al período 16001659», en David García Hernán (ed). La historia sin complejos: la nueva visión del Imperio Español (estudios en honor de John H. Elliott). San Sebastián de los Reyes, Madrid: Actas, 2010, págs. 176-203.

-, "Éxito y crédito. Funciones del hato de una actriz en la empresa teatral áurea», en Almudena García González, Felipe B. Pedraza Jiménez \& Rafael González Cañal (eds). Damas en el tablado. XXXI jornadas de teatro clásico, Almagro, 1, 2 y 3 de julio de 2008. Cuenca: Universidad de Castilla-La Mancha, 2009, págs. 53-83.

—, "La biblioteca de un autor de comedias en los albores del teatro barroco: Tomás de la Fuente», Boletín de la Real Academia de la Historia, 206.3 (2009), págs. 403-443.

—, "Ecos de comedia”: inluencias del teatro español en el sacro imperio y los Países Bajos en tiempos de los Austrias», en Paloma Flórez Plaza (ed.). Teatro 
$y$ fiesta del Siglo de Oro en tierras europeas de los Austrias [exposición]. Real Alcázar, Sevilla 11 abril-22 junio 2003. Castillo Real de Varsovia, Polonia 30 julio-6 octubre 2003. Madrid: Sociedad Estatal para la Acción Cultural Exterior de España, 2003, págs. 94-106. Accesible en línea: <http://www. accioncultural.es/publicacion.php?idarticulo $=5978>$.

—, "Las autoras de comedias en el siglo XviI: empresarias teatrales en tiempos de Calderón», en José Alcalá-Zamora y Queipo de Llano \& Ernest Belenguer Cebrià (eds). Calderón de la Barca y la España del Barroco. Madrid: Centro de Estudios Políticos y Constitucionales: Sociedad Estatal España Nuevo Milenio, 2001, 2 vols. T. 2 págs. 543-579.

—, «Peor está que estaba: la crisis hacendística, la cuestión del vellón y su reflejo teatral en tiempos de Calderón», en José Alcalá-Zamora y Queipo de Llano \& Ernest Belenguer Cebrià (coords.). Calderón de la Barca y la España del Barroco. Madrid: Centro de Estudios Políticos y Constitucionales, 2001, 2 vols. T. 1. págs. 189-210.

—, «Felipe II y los orígenes del Teatro Barroco», Cuadernos de historia moderna, 23 (1999), págs. 47-78. Accesible en línea: <http://dialnet.unirioja.es/ servlet/extart?codigo $=123203>$

—, «"Miserias de la comedia”. Algunos problemas del oficio de representar el último cuarto del siglo XvI», en José Juan Berbel Rodríguez (ed). En torno al teatro del Siglo de Oro. actas de las Jornadas XII-XIII celebradas en Almería. Almería: Instituto de Estudios Almerienses Diputación de Almería 1996, págs. 225-234. Accesible en línea: <http://www.dipalme.org/Servicios/ Anexos/anexosiea.nsf/VAnexos/IEA-SO12-p2/\$File/SO12-p2.pdf>

—, «La crisis económica durante el reinado de Carlos II y su influencia en el mundo del teatro", Diálogos hispánicos de Amsterdam, 8 (1989), págs. 649-668.

Sirera, Josep Lluis, «iIr más allá del texto? Los retos actuales de la historiografía teatral española», Teatro: revista de estudios teatrales, 21 (2007), págs. 211224. Accesible en línea: <http://hdl.handle.net/10017/10693>

Tropé, Hélène. «Valimiento y mecenazgo: Los artistas y los escritores ante el duque de Lerma, valido de Felipe III (1598-1621)», en (ed). La représentation du favori dans l'Espagne de Philippe III et de Philippe IV. Paris: Presses de la Sorbonne Nouvelle, 2010, págs. 131-180.

VEGA, Lope de. Corona trágica: vida y muerte de la serenísima reina de Escocia María Estuarda. Edición de Antonio Carreño-Rodríguez \& A. Carreño. Madrid: Cátedra, 2014.

-, "Los españoles en Flandes», en Antonio Cortijo Ocaña (ed). Comedias de Lope de Vega. Parte XIII. Madrid: Gredos, 2014. 2 vols. T. II págs. 909-1108.

—, Laurel de Apolo. Edición de Antonio Carreño. Madrid: Cátedra, 2007.

-, Porfiar hasta morir = Persistence until death. Edición de Antonio Cortijo Ocaña \& Adelaida Cortijo Ocaña. Barañáin (Navarra): EUNSA, 2004.

—, Rimas humanas y otros versos. Edición de Antonio Carreño. Barcelona: Crítica, 1998. 
Vega Ramos, María José. «Los pecados del lector. Delectación morosa y lecturas culpables en la teología moral del siglo XVI», en Eugenia Fosalba \& María José Vega (eds). Textos castigados: la censura literaria en el Siglo de Oro. Bern: Peter Lang, 2013, págs. 205-226.

Waltaus, Rima. «La comedia lopesca y el teatro holandés de principios del siglo xviI: Un temprano triunfo para Theodore Rodenburgh», en Henry W. Sullivan, Raúl A. Galoppe \& Mahlon L. Stoutz (eds). La comedia española y el teatro europeo del siglo XVII. Woodbridge: Tamesis, 1999, págs. 152-174. Zugasti, Miguel, "Lope de Vega y la comedia genealógica», Tintas. Quaderni di letterature iberiche e iberoamericane, 3 (2013), págs. 23-44. Accesible en línea: <http://www.cervantesvirtual.com/nd/ark:/59851/bmcj11x0>. 